\title{
The International Tribunal for the Prosecution of Foreign Fighters Responsible for Serious Violations of International Humanitarian Law and International Human Rights Law Committed in the Territory of the Syrian Arab Republic Since 2011
}

\section{Citation}

Dahabreh, Peter Cephas. 2019. The International Tribunal for the Prosecution of Foreign

Fighters Responsible for Serious Violations of International Humanitarian Law and International Human Rights Law Committed in the Territory of the Syrian Arab Republic Since 2011. Master's thesis, Harvard Extension School.

\section{Permanent link}

http://nrs.harvard.edu/urn-3:HUL.InstRepos:42004137

\section{Terms of Use}

This article was downloaded from Harvard University's DASH repository, and is made available under the terms and conditions applicable to Other Posted Material, as set forth at http:// nrs.harvard.edu/urn-3:HUL.InstRepos:dash.current.terms-of-use\#LAA

\section{Share Your Story}

The Harvard community has made this article openly available.

Please share how this access benefits you. Submit a story. 
The International Tribunal for the Prosecution of Foreign Fighters Responsible for Serious Violations of International Humanitarian Law and International Human Rights Law Committed in the Territory of the Syrian Arab Republic since 2011

Peter Cephas Dahabreh

A Thesis in the Field of International Relations

for the Degree of Master of Liberal Arts in International Relations

Harvard University

May 2019 
(C) 2019 Peter Cephas Dahabreh 


\begin{abstract}
The Syrian Civil War is an interesting case in geopolitics if one looks at the evolution of foreign fighters. What began as a demonstration in a southern village of Syria transformed into one of the most devastating conflicts of the twenty-first century. The war brought new challenges to the world as a consequence of this now almost decade-long civil war. Myriad challenges are all too apparent: refugees, terrorism, and reconstruction, among them.

The focus of this thesis is on foreign fighters, which I define as those involved in foreign terrorist organizations who continually challenge international law. Prior to the Syrian civil war, foreign fighters did not have extensive support. That came only with the temporary successes of the Islamic State of Iraq and Syria (ISIS) and other radical extremists during their zenith from 2014 to 2016. Today, the problem that needs to be resolved worldwide is how to handle the return of every foreign fighter as they return to their original homes. No corner of the globe is exempt since recruitment of these foreign fighters reached throughout six continents. Thousands of men and women joined ISIS, and now many will return home following the failure of the self-proclaimed caliphate.

ISIS declared its caliphate in 2014, but even before then it used horrendous tactics to recruit new members and seize territory and power; indeed, other Islamic extremist groups pursued similar activities. Many of the crimes committed during the Syrian civil war-rape, massacre, ethnic cleansing, and genocide — were carried out by members recruited into these groups.
\end{abstract}


That begs the questions: Will the world bring justice to the victims of this war? Can anything be done? If there is no court to hold accountable these violators of international law and international human rights, what recourse is there for holding these fighters accountable for actions that have ravaged and prolonged a conflict resulting in millions of displaced people and more than a half a million dead?

This thesis aims to answer the following question: What is the most viable option for holding foreign fighters accountable when it is determined that they violated international law during the Syrian civil war? My research suggests that a new international tribunal is required, one that can hold foreign fighters in the Syrian civil war accountable for their actions. Most domestic laws stop short, deciding instead to charge a foreign fighter with membership in a terrorism organization when he/she attempts to return home. Many entities and governments point to international courts as the most viable option for rendering judgment. However, I identify several hurdles in that path, which I discuss. In sum, my research efforts lead me to a more viable approach: establishing an international tribunal through the United National Security Council. To this end, I offer specific suggestions to bring this realistic option to fruition. 


\section{Dedication}

To my family and to the values of the United States of America. 


\section{Acknowledgments}

I would like to acknowledge and thank Professor Naz Modirzadeh, the Founding Director of Harvard Law School's Program on International Law and Armed Conflict, for her guidance, support, and leadership.

I would also like to thank Jennifer Allison, Librarian for Foreign, Comparative, and International Law at the Harvard Law School Library. Her assistance with researching American and European court cases was critical to my own research.

A special thank you to Dr. Doug Bond, who spent hours with me in his office regarding my thesis. The outcome of that patience and care has given me a new understanding of what inspires me the most. 


\section{Table of Contents}

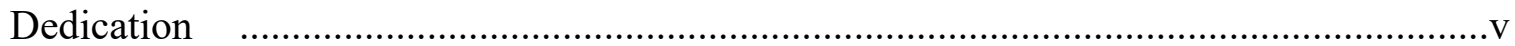

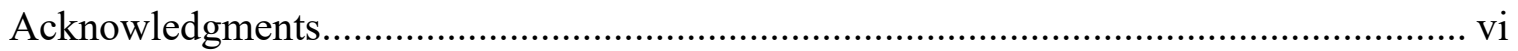

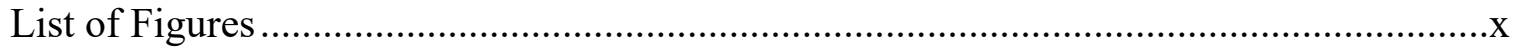

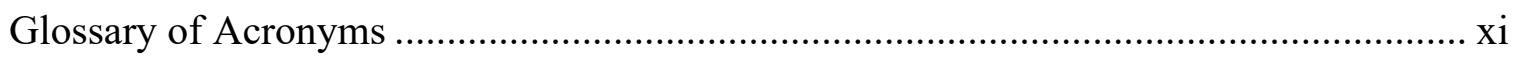

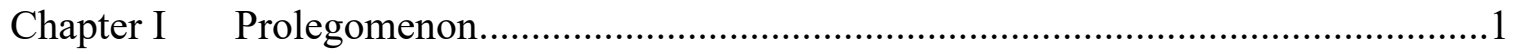

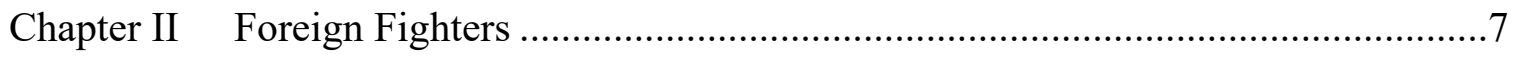

Who is a Foreign Fighter? .................................................................

Debate in International Law About Foreign Fighters ...............................11

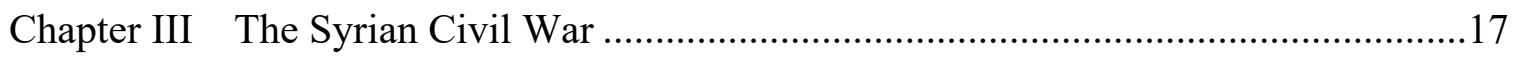

Buildup to Civil War ............................................................................. 18

Foreign Fighters in the Syrian Civil War ................................................20

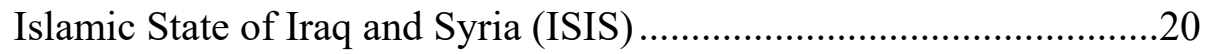

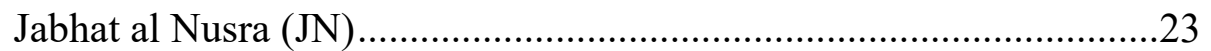

Islamic Revolutionary Guard Corps (IRGC) .................................23

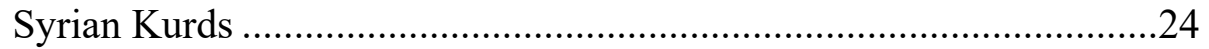

United States and Its Middle East Allies................................................25

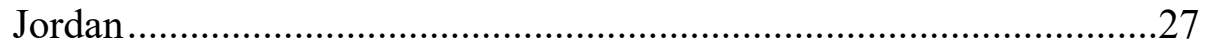

Saudi Arabia.............................................................................28 


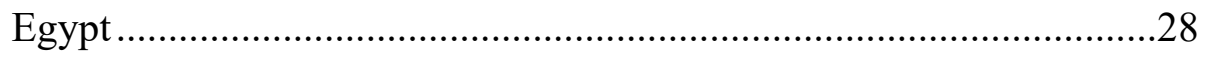

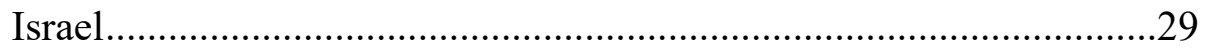

Russia and Its Pro-Assad Alliance ..............................................................29

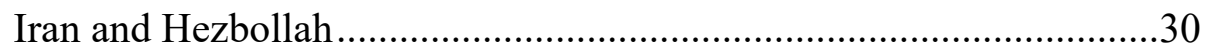

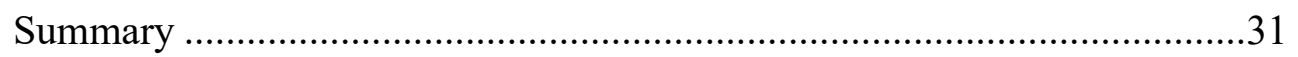

Chapter IV Violations of International Law Committed During the Syrian Civil War..33

Obstruction of Freedom of Expression .....................................................3

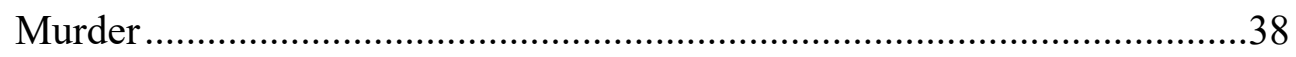

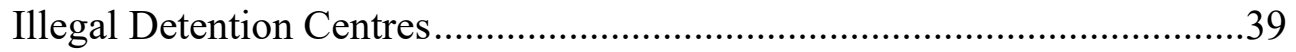

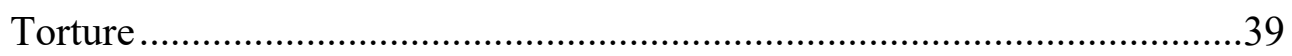

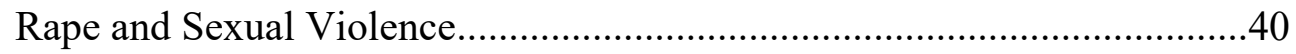

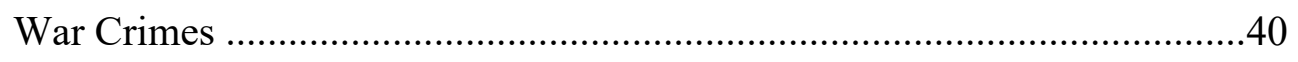

Recruiting and Using Children in Hostilities .............................................41

Attacking Protected Objects.....................................................................

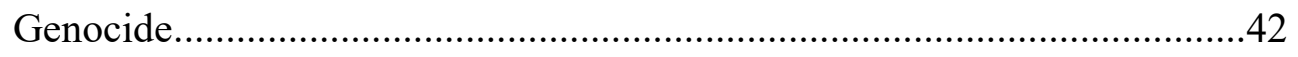

Crimes Against Humanity .....................................................................42

Chapter V Decentralized Prosecutions of Foreign Fighters .........................................4

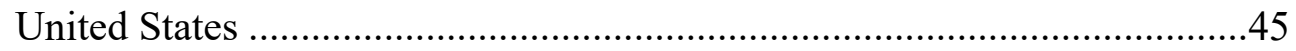

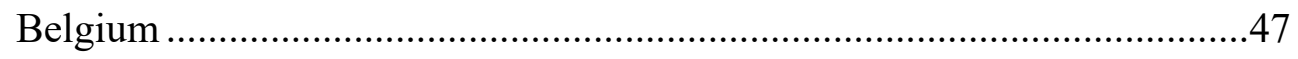

France

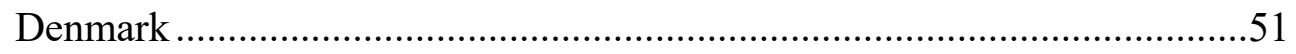

Summary of Decentralized Prosecutions …………………........................52 
Chapter VI Extraordinary Measures for Extraordinary Curcumstances ........................54

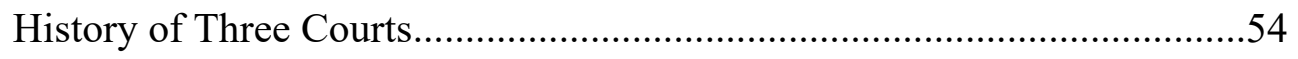

International Criminal Tribunal for the former Yugoslavia (ICTY) ...56

International Criminal Tribunal for Rwanda (ICTR)......................57

Special Tribunal for Lebanon .................................................59

Learning from Past Tribunals............................................................61

Chapter VII A New International Tribunal ….....................................................63

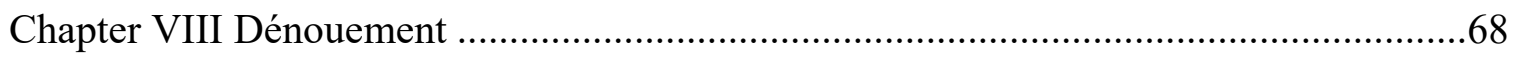

Chapter IX A Model: A Proposed Resolution ....................................................... 71

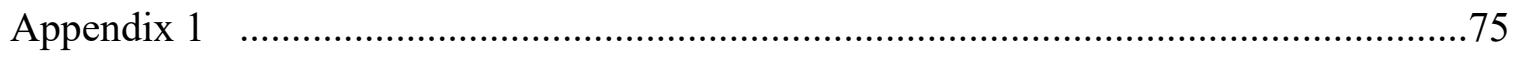

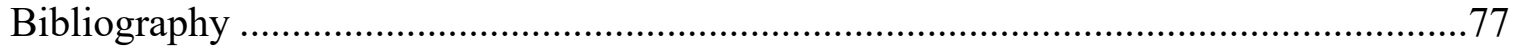




\section{List of Figures}

Figure 1 Numbers of Islamic State Fighters Returning to Their Home Countries ...........45 


\section{Glossary of Acronyms}

AQAP Al-Qaeda in the Arabian Peninsula

AQI Al-Qaeda in Iraq

AQIL Al Qaeda in Iraq and the Levant

FSA Free Syrian Army

HRC United Nations Human Rights Council

ICC International Criminal Court

ICL International Criminal Law

ICTY International Criminal Tribunal for the former Yugoslavia

ICTR International Criminal Tribunal for Rwanda

IHL International Humanitarian Law

IHRL International Human Rights Law

IIIM International Impartial and Independent Mechanism to Assist in the Investigation and Prosecution of Persons Responsible For the Most Serious Crimes Under International Law Committed in the Syrian Arab Republic Since March 2011

IRGC Islamic Revolutionary Guard Corps

ISIS Islamic State of Iraq and Syria

JN Jabhat al-Nusra

PKK Kurdistan Workers' Party 


$\begin{array}{ll}\text { PYD } & \text { Democratic Union Party (Kurdish) } \\ \text { UNHCR } & \text { United Nations High Commissioner for Refugees } \\ \text { UNIIIC } & \text { United Nations International Independent Investigation Commission } \\ \text { UNOHC } & \text { United Nations Office of the High Commissioner } \\ \text { UNSC } & \text { United Nations Security Council } \\ \text { YPG } & \text { People's Protection Units (Kurdish) }\end{array}$




\section{Chapter I}

\section{Prolegomenon}

Holding foreign fighters accountable for their activities in armed conflict is a problem that affects virtually every country in the world. It arises because there are no mechanisms in place to adequately address the topic of foreign fighters in the first place. Such fighters, who return to their original residence, are sometimes charged with domestic crimes, ${ }^{1}$ but the greater problem is the lack of adequate frameworks to prosecute returning foreign fighters who have committed crimes against international law. Some countries have taken it upon themselves to define due process and facilitate prosecution. However, I believe that to neutralize the continuing and threatened potential of foreign fighters, the international community must work together to identify and prosecute those who have violated international laws.

Following past wars, the international community came together to bring justice to bear on individuals who committed serious crimes. Tracking down and bringing to justice some of the participants in the Holocaust of World War II, or in conflicts in Rwanda, the former Yugoslavia, and Bosnia Herzegovina are examples of approaches utilized to bring some measure of resolution. These conflicts each gave rise to its own tribunal where responsible parties whom violated international law were prosecuted.

\footnotetext{
${ }^{1}$ The United Nations and several countries have passed laws prohibiting travel and participation with terrorist organizations. I cite several cases that shed more light on this issue.
} 
I argue that foreign fighters who now and in the past have participated in the Syrian civil war also require such a method to resolve the continuing humanitarian crisis that those fighters helped create. One way to solve this challenge is to establish an international tribunal through the United National Security Council, and then develop a workable mechanism that enforces international laws. My thesis demonstrates how this idea is the best solution for comprehensively addressing this problem.

My research begins by defining the concept of foreign fighters in Chapter II, providing background and context for the problem. The chapter also includes a discussion about the legal identity of foreign fighters. This identity is important given the transnational operations of the groups these fighters belong to in the Syrian civil war. The chapter then dives into the politics and agenda of several parties in the conflict. Some groups operate at the behest of world powers; some foreign fighters do not. The chapter clarifies the present danger of foreign fighters.

Throughout the thesis, special attention is directed toward the Islamic State of Iraq and Syria (generally referred to as ISIS, although some writers refer to it as IS). The distinctive quality that separates ISIS as a foreign fighter force with individual members is the function of the organization. That organization requires special attention, which I provide in this thesis. ISIS is recognized internationally as a terrorist organization that openly commits atrocities. It is not a political organization/force bolstered by one super power seeking to diminish the strength of another. ${ }^{2}$ ISIS differs in major ways from any

\footnotetext{
${ }^{2}$ One example of a foreign fighter force supported by a super power against another: the Seven Party Mujahideen Alliance was supported by the US (as well as Pakistan and Saudi Arabia) during the Soviet Union's invasion of Afghanistan. The Mujahideen Alliance was not a campaign of terror seeking to establish a state but rather defending a Muslim country against the Soviet invasion.
} 
other foreign fighter group. In an interview with Chuck Hagel during his tenure as US Secretary of Defense, he called ISIS a new phenomenon. Hagel said its uniqueness was evident from its level of organization, its presence and clever use of social media, and the depth of training given to its members. Hagel argued that this was the reason why ISIS was a "credibly powerful new threat."

I review the available literature regarding international law and foreign fighters, and offer a broader explanation as to why decentralizing the prosecution of foreign fighters is an inadequate solution. I provide information about international debates on foreign fighters, which brings a greater understanding of the contentious nature of the debate as well as the need for sensitivity when trying to define foreign fighters, especially the challenge of defining foreign fighters under international law. I briefly discuss international humanitarian law (IHL) and international human rights law (IHRL), and then speak to the contentious nature of the term "foreign fighter" when discussing how violations under these laws trigger the accountability of foreign fighters who participate in an armed conflict.

Chapter III transitions into the Syrian civil war crisis where the issue of foreign fighters is most apparent and pervasive. That war is a "chess match" that needs both chronological and geopolitical context in order to understand the various moving pieces. It is not a match between two individuals, but rather multiple actors moving back and forth within Syrian territory. The chapter provides crucial background about the war. A brief review of the so-called "Arab Spring" and its influence in Syria's civil war sets the

\footnotetext{
${ }^{3}$ Chuck Hagel, "ISIS: we've never seen anything like it," said US Defense Secretary Chuck Hagel in a video." https://www.theguardian.com/world/video/2014/nov/20/isis-us-defence-secretary-chuck-hagelvideo.
} 
stage for addressing the responses of the Syrian government. I investigate Syrian President Bashar Al-Assad's policies and actions toward demonstrators and then transition into a thematic overview of the war itself. A chronology of events then shifts into the geopolitical identity of the conflict to better understand the multiple lenses needed to analyze the crisis now bared.

Chapter IV considers several monitoring groups (Human Rights Watch, Amnesty International, United Nations) that look for violations of international law committed in Syria since 2011. To fully understand the nature of the atrocities committed during the war, I give examples of some of the crimes reported. This provides context for the challenges facing the international community. The violations occurred often during the conflict, and they beg for further consideration, especially if a domestic court were to attempt to handle the prosecution of a foreign fighter.

Examining how domestic courts have proven to be inadequate in prosecuting foreign fighters is dealt with in Chapter V. Throughout Europe and North America, foreign fighters who belonged (and may still belong) to terrorist groups are returning home from fighting in Syria. Many are charged with joining a terrorist organization but have evaded prison and are now walking the streets of their home cities and towns. ${ }^{4}$ Determining whether a foreign fighter committed violations of international laws is challenging. I argue that recognized groups on the ground in Syria need an adequate, centralized court system to which they can transfer and charge foreign fighter detainees.

\footnotetext{
${ }^{4}$ One example of an ISIS fighter now free: Belgian citizen Michael Delefortrie joined ISIS and fought in at least one battle. He was given a suspended three-year sentence and is currently free. For more information, see: https://www.newyorker.com/news/news-desk/what-happens-to-former-isis-fighters. (Accessed 20 February 2019.)
} 
Decentralizing such prosecution poses several problems that I will identify, as well as legal issues that could result in acquitting potential terrorists.

There is a fine line between foreign fighters who operate on behalf of a state and those who do not. Groups monitoring the war in Syria have reported extensively on the activities of both types of groups, and my research includes both types of fighters as I consider the question of accountability. Activities by the Islamic Revolutionary Guard Corps (IRGC), Hezbollah, and ISIS have been well documented, and their presence has often encouraged support for sanctions against them. ${ }^{5}$ However, I focus primarily on Islamic extremist groups like ISIS and Jabhat al-Nusra, and my research addresses which countries' domestic laws were used to prosecute returning foreign fighters.

More precedents will be needed to hold accountable those alleged to have committed serious crimes and to deter similar events from occurring, and my findings provide evidence that supports why justice must be pursued. In the past, international courts have sought to address this problem by utilizing ad-hoc tribunals. Two different tribunals, each representing an extraordinary threat, will be explored to determine what makes their circumstance exceptional and how the Syrian Civil War may require a similar measure.

The culmination of my research builds into what I believe is the answer to the problem. In Chapter VII, I propose the establishment of an "International Tribunal for the Prosecution of Foreign Fighters Responsible for Serious Violations of International Humanitarian Law or International Human Rights law Committed in the Territory of the

\footnotetext{
5 Jonathan Marcus, “Trump Re-imposes Iran Sanctions: Now What?” BBC News, November 3, 2018. https://www.bbc.com/news/world-middle-east-46075179. Accessed January 01, 2019
} 
Syrian Arab Republic.” This tribunal will focus specifically on foreign fighters who joined terrorist organizations. The tribunal will hold said foreign fighters accountable for any serious crimes they may have committed during the time they participated in Syria's civil war. The chapter lays out a blueprint of how an international tribunal could be established, and addresses which crimes would be covered under its jurisdiction. Using the examples of past tribunals like those established in Rwanda and former Yugoslavia, I detail how such courts would be relevant and necessary for bringing justice and restitution to bear on foreign fighters in the Syrian civil war. I also consider how the international community might see just how such a court could come to fruition based on Chapter VII of the United Nations.

Chapter VIII of the thesis summarizes counter-arguments that I anticipate might be put forward to dispute the viability of this approach to addressing the challenge of holding foreign fighters accountable. Indeed, several arguments may dispute the efficiency and plausibility behind this proposed international tribunal. However, my research has brought me to this conclusion that this is viable and will work.

In Chapter IX, I provide language that could be used in a UN resolution drafted in the Security Council and submitted to the Secretary-General. This is my sense of what could be developed to address the challenges I describe in this thesis. By approving such a Resolution to create a world tribunal, foreign fighters no longer have to be prosecuted in national courts, thereby lessening or ending decentralized prosecutions. Furthermore, the free flow of foreign fighters into terrorist organizations can be diminished or halted by setting this precedent for dealing with future violations of international law. 


\section{Chapter II}

\section{Foreign Fighters}

Throughout the twentieth and twenty-first centuries, the world has witnessed foreign fighters in several theaters of war: Spain in the $1930 \mathrm{~s},{ }^{6}$ Afghanistan in the $1980 \mathrm{~s}$ and 2000s, ${ }^{7}$ and the Syrian Civil War begun in 2011 and still ongoing as of this writing. In each instance, these armed conflicts have attracted foreigners from around the world to participate voluntarily.

This chapter explores the features that characterize foreign fighters. I begin by providing a definition of a foreign fighter. I build on that definition with a brief overview of debate among legal scholars, which highlights the need for a cogent definition of foreign fighters and is paramount for determining accountability. Among the debates considered are foreign fighters' rights to nationality and the global need to uphold human rights obligations, both of which are part of contemporary international laws.

\section{Who is a Foreign Fighter?}

The phenomenon of individuals leaving their homes to travel to another country and participate in an armed conflict is not unique. However, the nature of today's foreign

\footnotetext{
${ }^{6}$ Sebastiaan Faber, "Spain's Foreign Fighters: The Lincoln Brigade and the Legacy of Spanish Civil War," Foreign Affairs, Sept/Oct. 2016. https://www.foreignaffairs.com/reviews/review-essay/spain-sforeign-fighters. (Accessed August 31, 2018.)

${ }^{7}$ Maria Donnelly, Thomas Sanderson, and Zack Fellman, "Case Studies in History: Afghanistan, Bosnia, Chechnya," Center for Strategic and International Studies (CSIS), Transnational Threats Project, n.d. http://foreignfighters.csis.org/history/case-studies.html. (Accessed 20 February 2019.)
} 
fighters has forced that bland definition to evolve. Modern conflicts like the Syrian civil war have forced the international community to revisit the characteristics attributed to foreign fighters. For instance, the common denominator of travelling to participate in armed conflicts is far more ambiguous. The motivations of such individuals have evolved: foreign fighters today are intent on carrying out the agenda of a military or political group. The subtle nuance is membership in an organization aiming to carve out a state. Years earlier, a group called the Lincoln Brigade was comprised of Americans who volunteered in the fight against the fascist regime of Spain's Francisco Franco. International law viewed them as volunteers ${ }^{8}$ - a term that did not distinguish between national and foreigner fighters. Civilians, combatants, soldiers, and military groups that took up arms to participate in that conflict were classified as volunteers. Another feature that distinguishes foreign fighters in the Syrian civil war from those in earlier conflicts elsewhere is their organization capabilities. It was not until the recent wars in the Middle East that groups of foreign fighters sought to capture territory for the purpose of building a new state.

The term "foreign fighter" has many interpretations that lead to several questions: What defines an individual as a fighter? Is participation in combat the only characteristic of a fighter? Does travel to another country to be with a husband or to marry a jihadist make one a fighter (as some men and women have done in the Syrian civil war)? ${ }^{9}$ Once a fighter is identified, how do we define that fighter as foreign? How can we differentiate

\footnotetext{
${ }^{8}$ Donnelly, Sanderson, and Fellman, "Case Studies," 28.

${ }^{9}$ Aryn Baker, "How ISIS is Recruiting Women to Join,” Time, 6 Sept. 2014. www.time.com/3276567/ how-isis-is-recruiting-women-from-around-the-world/.
} 
between someone who is a foreign fighter and one who is simply a national returning from a conflict zone?

These questions and considerations form the basis of much of today's discussion and argument and complicate the possibility determining conclusions. For example, a Syrian was given refuge in France in 2012, and lived in Paris for three years before becoming radicalized and travelling back to Syria to fight. Can he be called a foreign fighter? He may have been given refuge by France and enjoyed certain state benefits, but how long must one reside in a territory to be considered a foreigner-either in France or elsewhere? These questions and more dominate the landscape of determining nationality and residency.

Defining the "foreign" characteristic and the "fighter" characteristic of foreign fighters has proved to be problematic. Numerous scholars have stepped forward with definitions of each term. The most widely used definition was crafted by Sandra Krähenmann, a leading scholar in international law who conducts research on the impact of counter-terrorism on human rights law and international humanitarian law. Her definition is this: Individuals, driven mainly by ideology, religion, and/or kinship, who leave their country of origin or their country of habitual residence to join a party engaged in an armed conflict. This definition was adopted by the Geneva Academy of International Humanitarian Law and International Law. ${ }^{10}$

Krähenmann's definition points to "ideology" as the distinguishing common denominator when defining a person as a foreign fighter. When discussing the ideology

\footnotetext{
${ }^{10}$ Thomas Hegghammer, and Jeffrey Colgan, "Islamic Foreign Fighters: Concept and Data." Paper presented at the International Studies Association Annual Convention (Montreal, Quebec, 2011): 6.
} 
behind many of ISIS' and Al-Qaeda's recruits, she incorporates in her definition any person who serves in any capacity in a party in an armed conflict. Authors Andrea de Guttry, Francesca Capone, and Christophe Paulussen take Krähenmann's definition a step further, and explicitly include foreign fighters fighting on the side of a government. ${ }^{11}$ Based on the Syrian civil war and the subsequent rise of ISIS, scholars who earlier supported Krähenmann's definition now believe that excluding state-sponsored parties does not adequately address the more comprehensive understanding needed in the definition of foreign fighters in the twenty-first century.

In another example, scholars Jeffrey Colgan and Thomas Hegghammer developed an expanded definition that includes key points in a checklist. According to these authors, the following elements characterize a foreign fighter:

- They are not overtly state-sponsored.

- They operate in countries that are not their own.

- They use insurgent tactics to achieve their ends.

- Their principal objective is to overthrow a single government or occupier in a given territory.

- Their principal motivation is ideological rather than material reward. ${ }^{12}$

What separates today's foreign fighters from their predecessors is their intention to carry out the agenda of a military or political group. Before there was some form of organized capacity among such fighters, and international law viewed them as

\footnotetext{
${ }^{11}$ Andrea De Guttry, Francesca Capone, and Christophe Paulussen, (eds.), Foreign Fighters Under International Law and Beyond (The Hague: T.M.C. Asser Press, 2016): 2.

${ }^{12}$ E. Karska, and K. Karski, "Introduction: The Phenomenon of Foreign Fighters and Foreign Terrorist Fighters," International Community Law Review, 18 (2016): 377-387.
} 
volunteers, ${ }^{13}$ a that term made no distinction between national fighters and foreigner fighters. Thus civilians, combatants, soldiers, and military groups that took up arms to participate in a conflict were classified as volunteers.

In the last few years, however, this definition is being questioned, and with the Syrian civil war, the definition has been challenged even further. One distinction that is apparent among foreign fighters in the Syrian civil war, which distinguishes them from earlier conflicts elsewhere, is the chain of command among the fighters. It was not until the Syrian war that groups of foreign fighters sought to capture territory and build a state within it. In the past, foreign fighters operated primarily subordinate to leading factions in the conflict.

In 2014, the international community came together to make some decisions owing to the surge of individuals who were leaving a country to join in a conflict in the Middle East. The United Nations Security Council (UNSC) adopted Resolution 2178, ${ }^{14}$ which condemned such individuals and empowered countries to impede those who seek to travel in order to join ISIS or other Al-Qaeda affiliates.

\section{Debate in International Law About Foreign Fighters}

This thesis is focused on the challenge of addressing the terrorist behavior of foreign fighters in the Syrian civil war. An international law definition for "terrorism" or "acts of terrorism" is arguably the central reason why a single international court does not

\footnotetext{
${ }^{13}$ Donnelly, Sanderson, and Fellman, "Case Studies," 28.

${ }^{14}$ United Nations Security Council, "Implementation of Security Council Resolution 2178 (2014) By States Affected by Foreign Terrorist Fighters." https://www.un.org/sc/ctc/wp-content/uploads/2016/.../FTFReport-1-3_English.pdf. (Accessed 20 February 2019.)
} 
have full jurisdiction over such crimes. As previously stated, being a foreign fighter does not alone constitute a crime. As legal debate about foreign fighters and international law continues, this section broadly addresses the complications of defining foreign fighters under international law.

Many legal factors come immediately to the forefront when considering an acceptable definition of a foreign fighter within international law. Triggering the contentious debate about legal mechanisms to hold foreign fighters accountable often begins with the fighter's mobility between the conflict zone and his/her habitual residence. This has resulted in a separate but relatable term, "foreign terrorist fighter" which attempts to isolate specific foreign fighters. This point took center stage during the Syrian civil war. Some nations were unwilling to accept repatriation of its citizens who turned foreign fighters. States that forfeited responsibility or accountability caused additional complication, which became apparent when scores of foreign fighters were detained by several groups in Syria. For example, the Syrian Kurds have detained over 1,000 men.

The issue of how to handle these detainees highlights the fact that the international community has only limited mechanisms for prosecuting individuals who have been judged guilty of war crimes, crimes against humanity, and violations of the Geneva Conventions. ${ }^{15}$ However, ISIS is a non-state actor, so the issue must be treated differently than for other states. France and Japan can take matters, including those pertaining to foreign fighters, to the International Criminal Court (ICC). Syria cannot

\footnotetext{
${ }^{15}$ A body of public international law whose purpose is to provide minimum protections, standards of humane treatment, and fundamental guarantees of respect to individuals who become victims of armed conflicts. https://www.law.cornell.edu/wex/geneva_conventions. (Accessed 20 February 2019.)
} 
since it is not a State Party to the Rome Statute, which is a requirement when seeking to bring a case before the ICC. ${ }^{16}$ According to the ICC, crimes against humanity are committed when foreign fighters conduct a "widespread and systematic attack directed against any civilian population," and it identifies four jurisdictions: genocide, crimes against humanity, war crimes, and crimes of aggression. ${ }^{17}$

Nationality also plays a role in international law, since deprivation of nationality is illegal. ${ }^{18}$ Mechanisms could be put in place in a state to strip an individual of his/her citizenship, however, requirements must also be in place for individuals to defend themselves under due process. This implies that if a state is aware that one of its nationals is traveling to Syria to participate in terrorist activity, the state cannot strip away his/her citizenship without giving him/her the opportunity to defend themselves.

Under international criminal law, foreign fighters can be found guilty of war crimes, and acts of terrorism can be considered a war crime if they are perpetrated as an intentional attack on civilians. Civilian protection from such an attack is covered under Additional Protocol II, part of the Geneva Conventions. ${ }^{19}$ Other violations are covered

\footnotetext{
${ }^{16} 123$ countries are States Parties to the Rome Statute of the ICC. Syria is not one of them. https://asp.icc-cpi.int/en_menus/asp/states\%20parties/pages/the\%20states\%20parties\%20to\%20the \%20rome\%20statute.aspx\#S . (Accessed 20 February 2019.)

17 "Rome Statute of the International Criminal Court. Article 5. 12 July 1999. http://legal.un.org/icc/statute/99_corr/2.htm. (Accessed 20 February 2019.)

${ }^{18}$ Universal Declaration of Human Rights, Article 15, which includes statements that everyone has the right to a nationality; no one shall be arbitrarily deprived of his nationality nor denied the right to change his nationality. http://www.claiminghumanrights.org/udhr_article_15.html .

${ }^{19}$ AP II is a 1977 amendment to the Geneva Conventions relating to the protection of victims of noninternational armed conflicts. It defines certain international laws that strive to provide better protection for victims of internal armed conflicts that take place within the borders of a single country. International Committee of the Red Cross (ICRC). https://ihl-databases.icrc.org/ihl/ INTRO/475?OpenDocument. (Accessed 20 February 2019.)
} 
under international criminal law (ICL). Like ICL, Hague Law concerns the actions of combatants. Hague Law takes into account actions against non-military objectives: churches, hospitals, historic monuments, etc. ${ }^{20}$

With this background, I come back to foreign fighters, as related to the Syrian civil war, who are suspected of terrorist acts. Terrorism is a term that is not authoritatively defined. Its uncertain definition raises challenges when attempting to charge a crime of terrorism to an individual. There have been precedents set in the past when an international criminal tribunal prosecuted individuals for terrorist activities. ${ }^{21}$ Two of those cases could be revisited to assist in defining criminal behavior and foreign fighter accountability in the Syrian civil war.

Another problem at the nexus of international law and foreign fighters is the debate that upholds the sanctity of human rights. Haykel Mahfoudh suggests that foreign fighters could be tried in national courts or under international humanitarian law. However, Mahfoudh points out that among all the crimes that could be used as a basis for prosecution, human rights obligations have not been among them. ${ }^{22}$ Daniele Amoroso argues that this debate can be siloed into three models that cover the contemporary debate about whether armed opposition groups or foreign fighters like those committed to ISIS are subject to and obligated to uphold human rights. He calls the three models

\footnotetext{
${ }^{20}$ de Guttry et al, Foreign Fighters, 167.

${ }^{21}$ For example, the Special Tribunal for Lebanon, and the International Criminal Tribunal for the former Yugoslavia.

${ }^{22}$ Haykel Ben Mahfoudh, "Protect, Respect and Remedy: A Framework for Accountability for Human Rights Violations Committed by Foreign Fighters," International Community Law Review, 18(2016): 418430. Available from: https://brill.com/view/journals/iclr/18/5/article-p418_4.xml. (Accessed 20 February 2019.)
} 
conservative, intermediate, and progressive. ${ }^{23}$ In the conservative model, Amoroso believes foreign fighter groups bear no responsibility to uphold human rights obligations. This model is grounded in the belief that armed opposition groups do not have the means to facilitate due process for captured enemies nor do they have sufficient infrastructure to respect human rights. Scholars like Amoroso reject this model because in the past the UN has condemned human rights violations committed by armed opposition groups. Others reject it based on the notion that many armed opposition groups do have any infrastructure to detain prisoners and hold a fair trial.

The intermediate model singles out armed opposition groups that exercise "effective power over a significant segment of society." 24 The intermediate model functions largely in the mainstream. ${ }^{25}$ What challenges the intermediate model is the notion that human rights obligations are not required in order to exercise control.

The third model in the debate on human rights obligations is the progressive model. As opposed to the conservative model, the progress model holds all armed opposition groups accountable for human rights. Accountability is not subject to territorial claim, but the larger infrastructure produces a wide net when there are more claims of territory. ${ }^{26}$ This model takes into consideration many of the rejections and

\footnotetext{
${ }^{23}$ As cited in Mahfoudh, "Protect, Respect and Remedy," 209.

${ }^{24}$ As cited in Mahfoudh, "Protect, Respect and Remedy," 209.

${ }^{25}$ Sandesh Sivakumaran, "Re-Envisaging the International Law of Internal Armed Conflict," European Journal of International Law 22 (2011): 219-64.

${ }^{26}$ de Guttry et al. Foreign Fighters Under International Law and Beyond. The Hague: Asser Press, 2016: 210 .
} 
objections of the other two models and fills some of the gaps that were created. Further, it does not draw a definitive marker of accountability.

As dialogue continues about the many pressing issues pertaining to foreign fighters, the threat also continues. What happens now and in the future could ultimately be a merger of the ideas and thoughts put forward in this chapter to identify, address, and solve the problem created by foreign fighters in the Syrian civil war. Scholars have shown their resourcefulness by addressing contemporary nuances. Yet, the world continues to use mechanisms that have been in place for some time without enhancing them to meet and deal with the continuing challenges. An understanding of the Syrian civil war is needed in order to make the leap from mechanisms already in place to designing others that fit the trials of our times. 


\section{Chapter III}

\section{The Syrian Civil War}

The Syrian civil war has its roots in what is commonly referred to as the "Arab Spring." The Arab Spring was a series of demonstration that caught the attention of the international community and led to the downfall of several autocratic regimes and forced reform in others. The self-immolation in 2010 of a Tunisian named Mohamed Bouazizi sparked shared frustrations throughout the Arab World. Bouazizi's protest was not in vain, as its effects began to reverberate across national borders. Inspired by actions domestic and national, others called for the dismantling of their governments. Bahrain, Egypt, Jordan, Libya, Morocco, Oman, Tunisia, and Yemen each faced various threats of instability. Among these, Egypt, Libya, Tunisia, and Yemen experienced the overthrow of dictators, ${ }^{27}$ while the leaders of Jordan, Morocco, and Oman escaped being overthrown by instituting reforms that were popular with the people. ${ }^{28}$ The success of these demonstrations led Syrian citizens to believe that their cause had equal merit. ${ }^{29}$

\footnotetext{
${ }^{27}$ Overthrown were Hosni Mubarak of Egypt, Muammar Gaddafi of Libya, Zine al-Abedine Ben Ali of Tunisia, and Abdallah Saleh of Yemen.

${ }^{28}$ D. Sorenson, Syria in Ruins: The Dynamics of the Syrian Civil War (Santa Barbara, CA: Praeger/ ABC-CLIO.

${ }^{29}$ Adam Baczko, Gilles Dorronsoro, and Arthur Quesnay, Civil War in Syria: Mobilization and Competing Social Orders." Problems of International Politics (Cambridge: Cambridge University Press, 2018).
} 
Syria includes numerous religions within its borders including Sunni, Shi'a, and other Muslim sects, as well as a Christian population that is the largest of the minority groups in Syria. Muslims comprise $87 \%$ of the total population: $74 \%$ Sunni and 13\% Shi'a. ${ }^{30}$ Contributing to the demographic are many ethnic groups such as Turkmen, Kurds, Arabs, Armenians, and Assyrians. The multi-ethnic and multi-religious nature of the nation helps to explain the sectarian lines within the country that helped bring about the Syrian civil war.

\section{Buildup to Civil War}

Syrian President Bashar Al-Assad succeeded his father and former President Hafez Al-Assad, in 2000. Syrians and non-Syrians alike believed Bashar would usher Syria into a modernized state. Many hoped he would liberalize the economy and pave a path toward a larger, more stable middle class. Sadly, the country has not seen these aspirations come to fruition. With the outbreak of the Arab Spring demonstrations, Syrians also began to make their voices heard, clamoring for a hand in shaping the future of Syria. As the number of demonstrators grew, and in response to mass demonstrations, Al-Assad refused to capitulate to the people's demands. Instead he resorted to past tactics that had kept the populace under control. He ordered economic concessions coupled with harsh military force. The inhabitants of the city of Daraa continued to demonstrate, and in response Al-Assad cut off all of the town's utilities and deployed 4,000 to 6,000 soldiers

\footnotetext{
${ }^{30}$ CIA, World Factbook (Washington, DC, 2019). https://www.cia.gov/library/publications/the-worldfactbook/geos/sy.html. Numbers include: Muslim 87\% (Sunni 74\% and Alawi, Ismaili, and Shia 13\%), Christian 10\% (includes Orthodox, Uniate, and Nestorian), Druze 3\%, Jewish (a few in Damascus and Aleppo).
} 
and dozens of tanks to suppress the resistance, and 25 people lost their lives. However, these methods for quelling the uprising proved futile as the peaceful demonstrators slowly grew into a national insurgency.

The following months displayed the heightened efforts of Al-Assad to restore security to Syria. In towns such as Hama, Homs, Ghouta, and elsewhere, the military rolled in to crush dissidents. Still, Bashar's brutal crackdown backfired, and it failed to deter further insurgency. In fact, the threat to Bashar intensified. In another blow to his government, soldiers in his army began to resign their posts. ${ }^{31}$ Assad responded with indiscriminate aerial bombing. ${ }^{32}$ By the end of 2011, Al-Assad forces were retreating from key towns and provinces. While the Syrian military was gone, these regions armed themselves to defend against the Syrian military, in the process organizing itself into the Free Syrian Army (FSA). What had begun as a ragtag band of disorganized but passionate citizens developed into a decentralized pseudo-army committed to defending towns and cities against Al-Assad.

The FSA became even more credible as soldiers and officers defected to the FSA side of the conflict. ${ }^{33}$ Although not a formal military force in the traditional sense of the word, the FSA collaborated with and made use of foreign fighters to combat Al-Assad's forces. A major problem with the FSA's effectiveness resulted from the lack of consensus regarding the end-result for Syria, and this lack of agreement translated to an unstable central command. Nevertheless, the group received aid (financial and military, lethal and

\footnotetext{
${ }^{31}$ Baczko, Dorronsoro, \& Quesnay, Civil War in Syria, 92.

${ }^{32}$ Baczko, Dorronsoro, \& Quesnay, Civil War in Syria, 93.

${ }^{33}$ Zachary Laub, “Who’s Who in Syria’s Civil War," Council on Foreign Relations, April 28, 2017. https://www.cfr.org/backgrounder/whos-who-syrias-civil-war. (Accessed December 31, 2018.)
} 
non-lethal) from international players like the United States. ${ }^{34}$ Now numbering 30,000 fighters, FSA was able to capture and control southern areas of the country, but in the northern territories they were forced to collaborate with Islamic extremist groups to plan joint campaigns. ${ }^{35}$ This insurgency claimed many towns, with the resulting unsafe atmosphere causing millions to flee the country. When millions of refugees fled Syria, the civil war turned into an international catastrophe. An even more serious threat was foreign intervention which increased through military, financial, and other aid.

Foreign Fighters in the Syrian Civil War

An added challenge was the growing involvement of foreign non-state fighters, such as Hezbollah and Islamic extremist groups like ISIS. The United States and its NATO allies opposed Russian moves taken through proxies. For example, Iran (a Syrian ally) provided its Islamic Revolutionary Guard Corps (IRGC) to assist Al-Assad's army to assert control, curtail the advancement of the FSA, and impede ISIS's land grabbing. Thus several groups, each focused on executing its own agenda, meant that the Syrian civil war would be an ongoing disaster for years to come.

Islamic State of Iraq and Syria (ISIS)

The most treacherous party vying for control in Syria is the Islamic State of Iraq and Syria, better known as ISIS. But even before Abu Bakr al-Baghdadi created ISIS, there was a terrorist group was known as Al Qaeda in the Arabian Peninsula (AQAP).

\footnotetext{
${ }^{34}$ Laub, "Who's Who in Syria's Civil War."

${ }^{35}$ Laub, "Who's Who in Syria's Civil War."
} 
The future Caliph of ISIS, Awwad Ibrahim al-Badri al-Sammarai (now known as Abu Bakr al-Baghdadi) dispatched AQAP into Syria. Having success in Syria, AQAP created Jabhat al-Nusra (JN). The leader of JN later disassociated himself from al-Baghdadi, and the two extremist groups engaged in a brutal campaign for superiority. JN clashed with ISIS to claim a stake in the Syrian civil war. JN's force of foreign fighters comprised approximately $30 \%$ of its total manpower. The number of foreign fighters who could be found in all aspects of the Syrian civil war presaged the unique threat that would engulf the entire region.

Ultimately, AQAP forces defeated JN forces, and then moved north of the Euphrates River where AQAP, led by al-Baghdadi, conquered the city of Raqqa. After Raqqa, AQAP was renamed Al Qaeda in Iraq and the Levant (AQIL). When AQIL captured Mosul, only then did al-Baghdadi proclaim himself Caliph of the Islamic State on June $29,2014 .{ }^{36}$ ISIS would go on to raze Syria and assault the Syrian populace through rape, torture, beheading, and other crimes.

Owing to international paralysis, ISIS was able to confiscate $60 \%$ of Syria's oil fields including al-Omar, its largest one. ISIS's campaign went beyond securing financial reward. In Iraq, ISIS captured Sinjar, home to the Yazidis, a religious minority in Iraq. In August 2014, ISIS killed 5,000 men and began selling Yazidi women into sexual slavery. Fearing for their lives, 50,000 Yazidis raced to nearby Mt. Sinjar where they became trapped, with ISIS waiting at the foot of the mountain to begin a brutal campaign to execute all Yazidis. However, international pressure mounted rapidly, causing U.S. President Barack Obama and other allies to order airstrikes to repel the ISIS forces.

\footnotetext{
${ }^{36}$ Sorenson, Syria in Ruins, 61-63.
} 
In 2014, the number of foreign fighters recruited into Islamic extremist groups in Syria surpassed that of Afghanistan and doubled the number involved in the Iraq War. ${ }^{37}$ Many Chechen and Southeast Asian brigades were mobilized in Syria to fight for ISIS. ${ }^{38}$ However, the majority of the foreign fighters involved with Islamic extremist groups, approximately $80 \%,{ }^{39}$ came from Arab or European countries—approximately 74 countries represented altogether. Many fighters arrived in Syria by going to Turkey and crossing that country's southern border into Syria. ${ }^{40}$

Islamist groups like ISIS recruit transnationally. Careful and clever use of social media drew recruits from more than 90 countries, many of them Western. Twitter, Facebook, YouTube, and other media have all been used to reach vulnerable individuals. ${ }^{41}$ During ISIS's peak, 30,000 fighters ${ }^{42}$ from all over the globe were recruited. $^{43}$

${ }^{37}$ Sorenson, Syria in Ruins, 126.

${ }^{38}$ Sorenson, Syria in Ruins, 129.

${ }^{39}$ Sorenson, Syria in Ruins, 130.

${ }^{40}$ Sorenson, Syria in Ruins, 131.

${ }^{41}$ David Malet, and Miriam J. Anderson, Transnational Actors in War and Peace : Militants, Activists, and Corporations in World Politics (Washington, DC: Georgetown University Press, 2017), 126.

${ }^{42}$ The Soufan Group, "Foreign Fighters: An Updated Assessment of the Flow of Foreign Fighters into Syria and Iraq." December 2015. http://soufangroup.com/wp-content/uploads/2015/12/

TSG_ForeignFightersUpdate_FINAL3.pdf. (Accessed December 31, 2018.)

${ }^{43}$ Malet and Anderson. Transnational Actors in War and Peace, 126. 
Jabhat al Nusra (JN)

Internationally recognized as a terrorist group, Jabhat Fatal al-Islam, or Jabhat alNusra (JN), moved from fighting in Iraq to expand its theater of war into Syria. With some 20,000 fighters, JN counts $30 \%$ of them as foreign fighters, ${ }^{44}$ utilizing terrorist attacks as its fundamental tactic. The group controlled Idlib Province in northern Syria for a period. It has been involved in fighting al-Assad forces, as well as FSA, ISIS, Kurdish, and Turkish forces. JN fought ISIS in order to expand JN-held territory before being suppressed by counter-terrorism operations. ${ }^{45}$

Islamic Revolutionary Guard Corps (IRGC)

The IRGC, an Iranian paramilitary organization, came to the aid of Al-Assad. Although not a foreign fighter force like ISIS and JN, they are foreign while fighting inside Syria. As a state-sponsored paramilitary organization, it also worked alongside non-state groups like Hezbollah. Hezbollah is made up of Lebanese Arabs, and its fighters are considered foreign during their participation in the Syrian civil war. The IRGC conducted military operations but unlike ISIS, the IRGC is welcomed by the AlAssad government. Hezbollah, a non-state terrorist organization and ally of Iran and Syria, also assists Al-Assad. Aligning themselves based on Shi'a kinship, Shi'a foreign fighters reached approximately $15,000 .^{46}$

44 John, Tara, "Everything You Need to Know About the Nusra Front and Their Rebrand," Time, July 28, 2016. http://time.com/4428696/nusra-front-syria-terror-al-qaeda/. (Accessed December 31, 2018.)

${ }^{45}$ Counter-terrorism forces includes the United States, NATO, Kurdish, and Russian military campaigns at degrading ISIS.

${ }^{46}$ Malet, and Anderson, Transnational Actors in War and Peace, 129. 
Syrian Kurds

Syrian Kurds have made a substantial contribution to dismantling ISIS. Foreign fighters fought alongside Syrian Kurdish forces in northern Syrian (Rojava) or with the Free Syrian Army. ${ }^{47}$ A successful and disciplined militia force, the Democratic Union Party (PYD), along with other Kurdish councils, created the People's Protection Units (YPG). The YPG protects Kurdish and non-Kurdish territories. Working primarily in Rojava, the YPG aimed most of the its campaigns against ISIS. The problem with YPG is its involvement with the Kurdistan Workers' Party (PKK), which is a terrorist group that has conducted operations against Turkey. American support of the YPG has created a rift between itself and its ally Turkey. For the United States, however, this group (which includes almost 50,000 fighters, ${ }^{48}$ is one of the best options in the Americans battle against ISIS. The YPG has attracted Kurds from all over the Middle East to protect Kurdish communities and other Syrian territories. The majority of foreign fighters in the YPG originate from Iraq, Iran, Turkey, and other areas with a Kurdish diaspora. ${ }^{49}$ Surprisingly, non-Kurdish fighters have travelled to fight alongside the Kurds. Journalists have not been able to confirm the number of fighters who are non-Kurdish; they have

\footnotetext{
${ }^{47}$ The majority of foreign fighters participating with Syrian Kurds were Kurds from surrounding territories. The Free Syrian Army had alliances with many state-sponsored militias belonging to the Sunni sect.

${ }^{48}$ Laub, "Who's Who in Syria's Civil War."

${ }^{49}$ Laub, "Who's Who in Syria's Civil War."
} 
determined that nationalities fighting with the Kurds include Americans, French, Australian, British, Spanish, and Dutch. ${ }^{50}$

\section{United States and Its Middle East Allies}

At the time of the Daraa incident in Syria, ${ }^{51}$ the U.S. had not signaled to the world that it would become involve in any new confrontations. President Obama had inherited two wars from his predecessor, so sentiment among many Americans was one of limited isolation, and Obama resisted involving the United States in Syria's growing conflict. As the U.S. appeared to sit back and allow Russia and Iran to aid Syria, Arab monarchies in the region were not happy. But in August 2012, President Obama made some saw as a virtually irreversible mistake. When Obama was asked what he would do if Assad began using chemical weapons, Obama responded:

We have been very clear to the Al-Assad regime, and also to other players on the ground, that a red line for us is we start seeing a whole bunch of chemical weapons moving around or being utilized. That would change my calculus. ... That would change my equation. We're monitoring that situation very carefully. We have put together a range of contingency plans. ${ }^{52}$

Obama's words returned to haunt him when the world learned about chemical

attacks carried out by Al-Assad in 2013 in a suburb of Damascus. This was a direct

\footnotetext{
${ }^{50}$ E. Bakker, and M. Singleton, "Foreign Fighters in the Syria and Iraq Conflict: Statistics and Characteristics of a Rapidly Growing Phenomenon." In: A. de Guttry, F. Capone, and C. Paulussen (eds). Foreign Fighters under International Law and Beyond. The Hague: T.M.C. Asser Press, 2016.

${ }^{51}$ During the Arab Spring protests, in March 2011 thousands of protestors began demanding an end to government corruption in Syria. On April 24, 2011, the Syrian Army began an 11-day siege of the city. Using tanks, helicopters and some 6,000 troops, 244 civilians were killed (many of them children) and a thousand people were arrested.

52 James Ball, “Obama Issues Syria a 'Red Line' Warning on Chemical Weapons," Washington Post, 20 August 2012. www.washingtonpost.com/world/national-security/obama-issues-syria-red-line-warningon-chemical-weapons/2012/08/20/ba5d26ec-eaf7-11e1-b811-09036bcb182b_story.html.
} 
challenge to the "red line" Obama had mandated. Faced with enforcing his strong words, Obama needed a diplomatic way out that would keep the American people from rallying to some type of humanitarian intervention. Surprisingly, Russian President Vladimir Putin provided the diplomatic corridor. Acting as a proxy, Russia agreed to remove and destroy Al-Assad's chemical stockpile. ${ }^{53}$ This proved to be a diplomatic success as it allowed the international community to witness the United States and Russia collaborating during the Syrian civil war.

Unfortunately, this effort to bring the humanitarian crisis in Syria to an end proved ultimately futile. Although Russia took the chemical stockpile from Assad, he again used chemical weapons in 2017. This time President Donald Trump ordered airstrikes as a direct response, hitting airbases that allegedly housed the airplanes used to carry out the chemical attacks.

Turkey

Following a terrorist attack, Turkey, a major U.S. ally, began military operations inside Syria in $2015 .^{54}$ At the time, Islamic State was using Turkey as a safe zone for mobilizing fighters and weapons, which eventually put Turkey at odds with the U.S., especially since the U.S. supports Kurdish rebel groups in northern Syria, and Turkey has had a longstanding and violent relationship with those groups, including YPG and the PKK. When Turkey bombed YPG targets in Syria, it drove a wedge between the U.S. and

\footnotetext{
${ }^{53}$ Larry Kaplow, "History of U.S. Responses to Chemical Weapons Attacks in Syria," National Public Radio, 14 Apr. 2018. www.npr.org/sections/thetwo-way/2018/04/13/602375500/history-of-u-s-responsesto-chemical-weapons-attacks-in-syria.

${ }^{54}$ Sorenson, Syria in Ruins, 92.
} 
Turkey. Turkey's actions arguably prevented the US-backed Kurdish forces from implementing successful missions.

Another U.S. allies in the region include Jordan, Saudi Arabia, Egypt, and Israel. All have been required to react defensively during the Syrian civil war.

Jordan

As a U.S. ally that shares a border with Syria, Jordan inevitably became exposed to the Syrian civil war, especially as Islamic State recruitment sought to entice Jordanians. Soon more than 2,000 Jordanians joined the ISIS mission to establish a caliphate. $^{55}$

The Syrian civil war challenged Jordan in many ways. Jordan used counterterrorism strategies against the threat to its northern border. However, in defiance of Jordan's campaign, ISIS broadcast the execution of a Jordanian pilot whose jet had been shot down. ${ }^{56}$ This tragedy led King Abdullah II of Jordan to arm Syrian tribesmen to fight against ISIS. Jordan is now home to many Syrian refugees.

\footnotetext{
${ }^{55}$ Daniel Byman, and Jeremy Shapiro, "Be Afraid. Be A Little Afraid: The Threat of Terrorism from Western Foreign Fighters in Syria and Iraq." Brookings Institution, 12 January 2015. www.brookings.edu/ research/be-afraid-be-a-little-afraid-the-threat-of-terrorism-from-western-foreign-fighters-in-syria-andiraq/. (Accessed 20 February 2019.)

${ }^{56}$ Omar Akour, "New Video Purports to show Jordanian Pilot Burned to Death by IS Militants," Christian Science Monitor, 3 February 2015. https://www.csmonitor.com/World/Latest-NewsWires/2015/0203/New-video-purports-to-show-Jordanian-pilot-burned-to-death-by-IS-militants. (Accessed 22 February 2019).
} 
Saudi Arabia

The Kingdom of Saudi Arabia has undertaken numerous efforts to remove the AlAssad government from power. One successful tactic was establishing a pro-Saudi commander in the Supreme Military Council—formed by the FSA, one of the largest anti-Assad forces in Syria. Saudi Arabia then provided the Council with equipment, including antitank weapons and missiles.

Saudi Arabia's interest in funding the FSA goes beyond helping one party in the conflict. Saudi Arabia's over-arching agenda is to defeat Iran since it embarked on a conflict dating back to 1979. Given Iranian presence in Yemen, Lebanon, Iraq, and Syria, the Syrian civil war is yet another opportunity for the two countries to battle one another through proxy for ultimate hegemony. In the process, Saudi Arabia has spent more than $\$ 100$ million in support of forces opposed to Iran in Syria. ${ }^{57}$

Egypt

Egypt's contribution to the Syrian civil war comes in the form of assisting diplomatically in an effort to unify moderate opposition forces. Holding conferences and arranging space for the forces to meet, Egypt is a regular hub for meetings of senior officials representing various opposition groups. ${ }^{58}$ Egypt found it necessary to intervene in the Syrian civil war because Islamic State operated in the Sinai Peninsula and in Libya.

\footnotetext{
${ }^{57}$ Tom Risen, “Arms Sales Boom Amid Iran, Saudi Arabia Proxy Wars," U.S. News \& World Report, 22 February 2016.

${ }^{58}$ Sorenson, Syria in Ruins, 107.
} 
Israel

The Syrian civil war represents another chapter in Israel's troubled relationship with Syria. Israel has occupied the Golan Heights in southwest Syria since 1967. Both Islamic State and JN operate in the Golan Heights. Complicating matters even further, two of Israel's sworn enemies, Hezbollah and Iran, currently operate on the ground in Syria, and each group has made provocative attempts on Israeli targets. As Iran encroaches on Israeli sovereignty, Israel has taken measures to subdue further acts of intimidation. $^{59}$

\section{Russia and Its Pro-Assad Alliance}

Russia, Iran, and Hezbollah have been relentless forces in the effort to secure AlAssad's dominance in Syria. In September 2015, Al-Assad was losing large swaths of territory to Islamic State and other opposition forces. Russian President Putin, fearing a collapse of this ally, deployed troops into Syria to quell the IS threat. The entry of Russian forces is legal under international law because Al-Assad made a formal request for Russia's assistance. Perceiving that the real threat to Al-Assad was the credibility of Syrian opposition forces, Putin sought to destroy that threat prior to targeting Islamic extremist groups. Doing this would point the focus on a threat that the rest of the international community could agree to attacking collectively. Putin succeeded in making the FSA and other opposition militias irrelevant, which allowed Al-Assad to regain

\footnotetext{
${ }^{59}$ Times of Israel Staff, "IDF Official Said to Confirm Attack in Syria: 'First Strike on Iranian Targets'." Times of Israel, 16 April 2018, www.timesofisrael.com/idf-official-confirms-attack-in-syriafirst-strike-on-live-iranian-targets/.
} 
control of key territories. ${ }^{60}$ Putin endured considerable criticism for bombing opposition forces rather than focusing on Islamic State. ${ }^{61}$

For Putin, however, maintaining one of his few allies in the Middle East was not negotiable. Syria sits on the Mediterranean Sea, with strategic ports capable of supporting economic and military functions. Al-Assad's regime received long needed crucial support to bring down the opposition. The international community was highly concerned with Russia's commitment to Syria. Fears of an indefinite Russian presence in Syria caused neighboring countries to worry about Iranian expansion into the Arab world via Syria. But in 2016, Putin pulled Russian troops out after suppressing opposition forces and boosting Al-Assad's position as the leader of Syria. ${ }^{62}$

Iran and Hezbollah

Iran uses its Shi'a kinship with Al-Assad to bolster its support for the regime. Further, Iran's ally in southern Lebanon, Hezbollah, operates in Syria to aid Al-Assad. By establishing a significant military presence in the Syrian conflict, Iran and Al-Assad have put in place a winning strategy. Iran and Hezbollah sent Shi'a militias from neighboring Iraq and elsewhere to fight in support of Al-Assad's government. Some Shia militias have come from as far as Afghanistan and Pakistan. The success of mobilizing

\footnotetext{
${ }^{60}$ Hwaida Saad, "Syria Regains Control of Damascus After Seven Years of Fighting," New York Times.9 June 2018. http://www.nytimes.com/2018/05/21/world/middleeast/syria-damascus-rebels.html. (Accessed December 31, 2018.)

${ }^{61}$ Alina Polyakova, "Putin’s True Victory in Syria Isn’t over ISIS,” The Atlantic, 26 February 2018. www.brookings.edu/opinions/putins-true-victory-in-syria-isnt-over-isis/. (Accessed 22 February 2019.)

${ }^{62}$ Sorenson, Syria in Ruins, 105.
} 
these Shi'a militias contributed to collapse of the Islamic State. In total, the Shi'a militia groups number approximately $25,000 .^{63}$

For Hezbollah to continue, it needs Bashar Al-Assad to remain in power. Through Syria, Hezbollah receives weapons, technology, and advisory support from Iran. ${ }^{64}$ The ascension of the FSA (backed by U.S, Saudi Arabia, and other opposition forces) would threaten the land corridor that is essential in order for Hezbollah to obtain that Iranian support. With forces numbering approximately $8,000^{65}$, Hezbollah has proven to give some advantage to Bashar Al-Assad.

\section{Summary}

The Syrian civil war as it stands in 2019 could not be foreseen in that fateful summer of 2011. The civil war has wrought disaster in the country, becoming a humanitarian crisis for millions of displaced Syrians and other refugees. In addition, thousands of foreign fighters have crossed into Syria to fight on behalf of religious or ethnic groups. While inside Syria, these foreign fighters continue to commit grave crimes against international law. Today that 2011 conflict has become a political and military crisis that continues to challenge world powers daily.

\footnotetext{
${ }^{63}$ Sorenson, Syria in Ruins, 105.

${ }^{64}$ Laub, "Who's Who in Syria’s Civil War."

${ }^{65}$ Laub, "Who's Who in Syria's Civil War."
} 
The Syrian civil war has so far created more than 5.6 million refugees. ${ }^{66}$ The death toll as of October 2018 stands at more than 500,000 people. But the end of this war is not yet in sight given Al-Assad's success in capturing key territories. On the positive side, Islamic State's presence is almost eradicated, and Islamist groups with thousands of foreign fighters no longer operate as they once did. Ultimately, those foreign fighters will return to their original national residence - and that brings us back to the crux of this thesis: how and/or will the international community prosecute foreign fighters who committed atrocities and breached international human rights laws?

${ }^{66}$ UN High Commissioner for Refugees (UNHCR), “Syria Regional Refugee Response,” Updated 20 December 2018. https://data2.unhcr.org/en/situations/syria\#_ga=2.73354515.1220391432.15398847804235111.1539884780 . (Accessed December 31, 2018.) 


\section{Chapter IV}

Violations of International Law Committed During the Syrian Civil War

This chapter describes several categories of violations against international law, with the aim of revealing the nature of the crimes committed by foreign fighters in the Syrian civil war. The reader should note that the crimes discussed below, which were and continue to be, committed by foreign fighters, are distinct from those committed by the country of Syria (formally known as the Syrian Arab Republic) under Bashar Al-Assad. Although many government crimes have been reported, they are not reviewed here, as they are beyond the scope of the thesis. Syria is a recognized government, so Syrian officials can be brought to justice through legal mechanisms currently available under international law. Unfortunately, this may not happen because of geopolitical challenges surrounding Syria's leadership and the conduct of this war, so my focus is solely on crimes committed by foreign fighter groups.

Crimes by these foreign fighters have been documented by several groups, including the UN High Commissioner for Refugees (UNHCR), the UN Human Rights 
Council (HRC), ${ }^{67}$ and the UN Independent Impartial and Independent Mechanism (UNIIIM). ${ }^{68}$

For the sake of brevity, this chapter includes only reports that have been documented by the HRC. The reports were created after hearing hundreds of interviews that corroborated the horrendous stories documents during the conflict. ${ }^{69}$ My goal for this chapter is to put forward unequivocally that crimes like those mentioned in the reports merit a type of "supra-court" created specifically to prosecute the criminals who have perpetrated these crimes.

By June 2012, the HRC noted in their reports "abuses by unknown perpetrators",70 (referring to entities independent from government forces or recognized opposition groups) that were committing violations of international law. Such activities became

${ }^{67}$ UNHRC was established in August 2011 to monitor the deteriorating situation in Syria. Resolution S-17/1 declares: "Decides to dispatch urgently an independent international commission of inquiry, to be appointed by the President of the HRC, to investigate all alleged violations of international human rights law since March 2011 in the Syrian Arab Republic; to establish the facts and circumstances that may amount to such violations and of the crimes perpetrated; and where possible to identify those responsible with a view to ensuring that perpetrators of violations, including those that may constitute crimes against humanity, are held accountable."

${ }^{68}$ On 21 December 2016, the UN adopted Resolution 71/248 establishing the UNIIIM to investigate and prosecute persons responsible for the most serious crimes under international law committed in Syria since March 2011. It is generally referred to as "the Mechanism," or "IIIM." Its mandate is "to collect, consolidate, preserve and analyze evidence of violations of international humanitarian law and human rights violations and abuses and to prepare files in order to facilitate and expedite fair and independent criminal proceedings, in accordance with international law standards, in national, regional or international courts or tribunals that have or may in the future have jurisdiction over these crimes, in accordance with international law." The IIIM is neither a prosecutor's office nor a court. It collects and analyzes information and evidence to assist criminal proceedings in courts or tribunals that have or may in the future have jurisdiction over these crimes. The IIIM seeks to support accountability processes aimed at bringing about justice for the victims of serious international crimes committed in Syria since March 2011. https://iiim.un.org/mandate/.

${ }^{69}$ First Report of the Commission of Inquiry on the Syrian Arab Republic, Report A/HRC/S17/2/Add.1 (23 November 2011).

70 United Nations Human Rights Council (UNHRC), "Rule of Terror: Living under ISIS in Syria," Report of the Independent International Commission of Inquiry on the Syrian Arab Republic, Report A/HRC/27/CRP.3 (19 November 2014), Paragraph 24. 
clearer as the reports were prepared. For example, wherever ISIS occupied areas with diverse ethnic and religious communities, minorities were forced either to assimilate or flee. The armed group had undertaken a policy of imposing discriminatory sanctions such as taxes, forcing conversion on the basis of ethnic or religious identity, destroying religious sites, and systematically expelling minorities. The evidence showed a pattern of violent acts directed against certain groups with the intent to curtail and control their presence within ISIS areas.

In its Third Report in June 2012, the HRC described an emerging actor in the conflict:

Several radical Islamic armed groups have emerged in the country. The most important is the Al-Nusrah Front for the People of the Levant, a group allegedly linked with Al-Qaida, which claimed responsibility for several attacks, including suicide bombings against Government forces and senior officials. ${ }^{71}$

Identifying which laws were applicable for holding opposition forces and foreign fighter groups accountable, in paragraph 134 the HRC went on to describe how non-state groups were responsible:

Although not a State party to the Geneva Conventions, organized armed groups must nevertheless abide by the principles of international humanitarian law. During non-international armed conflicts, serious violations of international humanitarian law committed by members of such groups are prosecutable as war crimes. Non-State actors may also bear responsibility for gross abuses of human rights, in particular those that amount to international crimes. The commission identified such violations, including murder, extrajudicial execution and torture, perpetrated by members of anti-Government groups. ${ }^{72}$

\footnotetext{
${ }^{71}$ Third Report of the Commission of Inquiry on the Syrian Arab Republic, Resolution A/HRC/21/50, (15 August 2012), Paragraph 30.

${ }^{72}$ Third Report, Paragraph 134.
} 
The HRC's report also tackled an individual's accountability regardless of his/her association:

Whether members of Government forces or anti-Government groups, those who intentionally commit the crimes identified in the present report bear responsibility. In addition, those who order these crimes to be committed (or plan, instigate, incite, aid or abet) are also liable. The commission received consistent evidence that mid- and high-ranking members of Government forces were directly involved in illegal acts. Defectors stated that commanders ordered their subordinates to shoot civilians and hors de combat fighters, and to torture and mistreat detainees. Orders were often enforced at gunpoint, and anyone hesitating to comply risked arrest or summary execution. Evidence showed that widespread looting and destruction of property occurred with the acquiescence of commanders. ${ }^{73}$

In its reports, the HRC made clear its view of the gravity of the deteriorating situation in Syria when it concluded that the level of criminal activity in Syria met the threshold for describing the Syrian civil war as a non-international armed conflict. ${ }^{74}$ This threshold is important because the conflict now demanded further legal consideration. The HRC recognized that while non-state actors could not participate in international human rights treaties, they still must adhere to core human rights principles that bound them to international human rights law.

As the Syrian civil war continued, the list of violations against international law grew massive. Among the serious crimes committed by foreign fighters the reader considerable detail about a violation as it was reported by the HRC. These reported violations are not headline news but objective accounts of events that occurred, and continue to occur in Syria throughout this ongoing, almost decade-long civil war. What is

\footnotetext{
73 Third Report, Paragraph 135.

74 Third Report, Annex II.3.
} 
vexing to many is the unwilling of the international community to intervene in such criminal behavior and stop it from expanding throughout the region and into the world.

The crimes listed in the sections below make clear that these crimes and the criminals who perpetrate them can, realistically, only be prosecuted in an international tribunal sanctioned by the United Nations. Each of the sections presents a direct description from a UNHRC Report.

\section{Obstruction of Freedom of Expression}

Paragraph 20. In areas under the armed group's control, civilians have experienced a relentless assault on their basic freedoms. ISIS enforces its rules summarily, inflicting harsh penalties discriminating against those who transgress or refuse to accept their self-proclaimed rule. ISIS has obstructed the exercise of religious freedoms, the freedom of expression, assembly and association, which are guaranteed by international law. The group has systematically enforced its edicts through its Al-Hisbah morality police to conduct constant surveillance within local communities. Children have been asked to inform on their parents' compliance with ISIS rules. Civilians who fled described a rapid imposition of strict social instructions followed by brutal enforcement. ISIS has attacked social and cultural practices - including weddings, musical events and traditional ceremonies - deemed incompatible with their self-proclaimed beliefs in both urban and rural areas, demonstrating their intent to eradicate these aspects of Syrian culture. $^{75}$

\footnotetext{
${ }^{75}$ UNHRC, “Rule of Terror,” Paragraph 20.
} 
Murder

Paragraph 33. The mutilated bodies of male victims are often placed on display, a warning to the local population of the consequences of failure to submit to the armed group's authority. One man, a witness to the killing of a 16-year-old boy in Al-Ashara (Dayr Az-Zawr), said the boy's body was hung on a cross in a public square "for people to see what it looks like to be punished by ISIS." 76

Paragraph 4. Through the use of unguided mortars, the abovementioned attacks carried out by Faylaq ar-Rahman and/or Hay'at Tahrir al-Sham and Ahrar al-Sham killed and maimed hundreds of civilians, amounting in each documented instance to the war crime of launching indiscriminate attacks. The attacks seriously contravened the most basic human rights of persons, including the right to life, liberty and security of person. Numerous similar attacks were documented during the period under review. The repeated, indiscriminate shelling of Damascus city and Rif Damascus by these groups further amounted to the war crime of intending to spread terror among civilians residing in Government-held areas. Moreover, even if carried out with the purpose of inducing Government forces to cease their unlawful attacks, armed and terrorist groups did not have the right to resort to countermeasures against persons not taking a direct part in hostilities. ${ }^{77}$

\footnotetext{
${ }^{76}$ UNHRC, "Rule of Terror," Paragraph 33.

${ }^{77}$ UNHRC, Report A/HRC/39/65 (9 August 2018), Paragraph 4.
} 


\section{Illegal Detention Centres}

Paragraph 38. ISIS has set up detention centers in former Government prisons, military bases, hospitals, schools and in private houses. Former detainees described being beaten, whipped, electrocuted and suspended by their arms from walls or the ceiling. Witnesses to public executions remarked that the victims often bore signs of prior beatings. Detainees are held in dirty and overcrowded cells. Many spent long periods of time in handcuffs. Detainees interviewed stated that neither they nor their cellmates received medical treatment. One detainee recalled a FSA fighter being left in his cell beaten, with his hands cuffed behind his back and an open fracture on his leg. ${ }^{78}$

\section{Torture}

Paragraph 39. ISIS has sought to control the flow of information in the areas it controls. Scores of Syrian journalists and human rights activists have been abducted, disappeared, tortured and executed. Their targeting largely failed to attract widespread media attention. As early as June 2013, ISIS began to abduct and torture Syrian journalists in Aleppo and Ar-Raqqah governorates. Former prisoners stated that the most brutal treatment inside ISIS detention centers was meted out to those suspected of being part of other armed groups, local media workers, and fixers working with international journalists. ${ }^{79}$

\footnotetext{
${ }^{78}$ UNHRC, Report A/HRC/39/65, Paragraph 38.

${ }^{79}$ UNHRC, Report A/HRC/39/65, Paragraph 39.
} 


\section{Rape and Sexual Violence}

Paragraph 51. Unmarried women-whom ISIS considers to be females over the age of puberty — pose a particular threat to the armed group's enforced social order. Parents of unmarried women and girls are terrified of their daughters being forced to marry ISIS fighters and as a result, early marriage is on the rise. Their fears are not unfounded. There are distressing accounts of fighters taking girls as young as 13 years old away from their families, resulting in violations of international humanitarian law and acts that amount to war crimes of cruel treatment, sexual violence, and rape. ${ }^{80}$

\section{War Crimes}

Paragraph 43. As an organized armed group exercising effective control over territory, ISIS has an obligation to ensure humane treatment. By regularly using violence to life, torture, mutilation, cruel treatment, ISIS is violating binding international humanitarian law. Its commanders can be held individually responsible for the ensuing war crimes. ${ }^{81}$

Paragraph 44. Subjecting persons to mutilation, by permanently disfiguring or disabling them through the removal of appendages amounts to the war crime of mutilation, cruel treatment and torture. Displays of dead, mutilated bodies are deliberate acts

\footnotetext{
${ }^{80}$ UNHRC, Report A/HRC/39/65, Paragraph 51.

${ }^{81}$ UNHRC, "Rule of Terror," Paragraph 43.
} 
intended to humiliate and degrade the victims and their family, amounting to the war crimes of outrages upon personal dignity. ${ }^{82}$

\section{Recruiting and Using Children in Hostilities}

Paragraph 51. The Commission continues to receive numerous allegations of children being recruited, placed in training camps and, in some cases, sent to active front lines. In March, for example, one 14-year-old boy joined the Syrian Democratic Forces in Tal Abyad, Ar-Raqqah, without the consent of his parents. He had approached a Syrian Democratic Forces recruitment centre in Tal Abyad voluntarily, was accepted by authorities of the Forces, and was killed in combat in early June in Ar-Raqqah countryside. Representatives of the Syrian Democratic Forces communicated the news of the boy's death to his family, but did not allow the family to bury him, instead burying him in a cemetery for "martyrs." Numerous accounts of ISIL militants recruiting, training, and using children in Ar-Raqqah also continue to be received. ${ }^{83}$

\section{Attacking Protected Objects}

Paragraph 25. Between September and October 2013, ISIS fighters attacked three Christian churches in Ar-Raqqah governorate, destroying the Greek Catholic church; occupying Al-Shuhada Armenian Orthodox church in Raqqah city and burning an Armenian church in Tel Abyad. As ISIS spread throughout eastern

\footnotetext{
${ }^{82}$ UNHRC, “Rule of Terror,” Paragraph 44.

${ }^{83}$ UNHRC, Report of the Independent International Commission of Inquiry on the Syrian Arab Republic, Report A/HRC/36/55 (8 August 2017), Paragraph 51.
} 
Syria, Christians and their places of worship continued to be attacked. In

September 2014, ISIS fighters destroyed an Armenian church in Dayr Az-Zawr. ${ }^{84}$

\section{Genocide}

Refers to ISIS campaign against the Yazidi in Iraq, where ISIS was also active. This is a crime against international human rights law. ${ }^{85}$

\section{Crimes Against Humanity}

Paragraph 29. Perpetrated as a widespread and systematic attack against the Kurdish civilian population, these acts amount to a crime against humanity by forcible displacement. According to former residents, attacks on Shi'a Husaynias and homes in Ar-Raqqah caused mass displacement, while others were forced to convert to Islam in order to survive.

The complete destruction of the Uwais Al-Qarni Shi'a Mosque and the desecration of seventh century tombs in Ar-Raqqah were carried out on 31 May 2014 as part of an assault against Shi'a in the area. Sunni mosques constructed around tombs or shrines of religious figures have been considered idolatrous and also destroyed by ISIS. ${ }^{86}$

\footnotetext{
${ }^{84}$ UN Human Rights Council. "Rule of Terror," Paragraph 25.

${ }^{85}$ UN Office of the High Commissioner (UNOHC), "Statement by the Commission of Inquiry on Syria, on the second anniversary of the August 3, 2014 attack by ISIS on the Yazidis," 3 August 2016. https://www.ohchr.org/EN/NewsEvents/Pages/DisplayNews.aspx?NewsID=20330\&LangID=E. (Accessed 23 February 2019.)

${ }^{86}$ UNHRC, “Rule of Terror,” Paragraph 29.
} 
These violations led the HRC to determine that foreign fighter groups, including ISIS, has committed violations to both international humanitarian law and international human rights law. The HRC advocated for establishing mechanisms to hold ISIS (as one group comprised largely of foreign fighters) accountable for these crimes. ${ }^{87}$ Since the HRC and other bodies were demanding a mechanism for holding foreign fighters accountable, it was clear that an internationally recognized tribunal must be conceived and implemented. To date, the international community has failed in its efforts to deter these groups since the commencement of the civil war almost a decade ago. Shying away from developing such a mechanism allows more criminal foreign fighters to return to their original residence where - without some method of ascertaining guilt or complicity - they will simply escape justice and, worse, could continue to violate international laws.

\footnotetext{
${ }^{87}$ UNHRC, "Rule of Terror," Introduction.
} 


\section{Chapter V \\ Decentralized Prosecutions of Foreign Fighters}

This chapter provides court cases from the United States, Belgium, France, and Denmark to give the reader an overview of court proceedings that have already occurred in matters of dealing with returning foreign fighters. Citing a few cases from each country, I draw conclusions about the effectiveness of current mechanisms in place. Ultimately, I point out that the decentralized manner in which the international community has dealt with this issue has indirectly contributed to the ongoing conflict in Syria and the earlier growth of ISIS.

Among others, two challenges arise from prosecuting foreign fighters: the jurisdiction of a court, and the continually evolving problem of how to hold foreign fighters accountable. Many fighters have been detained by U.S-backed Kurdish forces and Iraqi forces, posing a particular challenge to.Kurdish authorities around the issue of international security when many of these fighters return to their home country and residence. The international community struggles to recognize and understand the threat of returning foreign fighters, often resulting in inadequate responses or prosecutions. Several countries have in fact refused to repatriate their citizens who became foreign fighters ${ }^{88}$ thus indicating an unwillingness to uphold the UN Global Counter-Terrorism

\footnotetext{
${ }^{88}$ Savage, Charlie. "As ISIS Fighters Fill Prisons in Syria, Their Home Nations Look Away". The New York Times. July 18, 2018.
} 
Strategy. ${ }^{89}$ This suggests that perhaps some nations do not have the capacity to handle prosecutions or the ability to deal with threats brought by returning foreign fighters now living domestically. Figure 1 gives some indication of the number of returning foreign fighters.

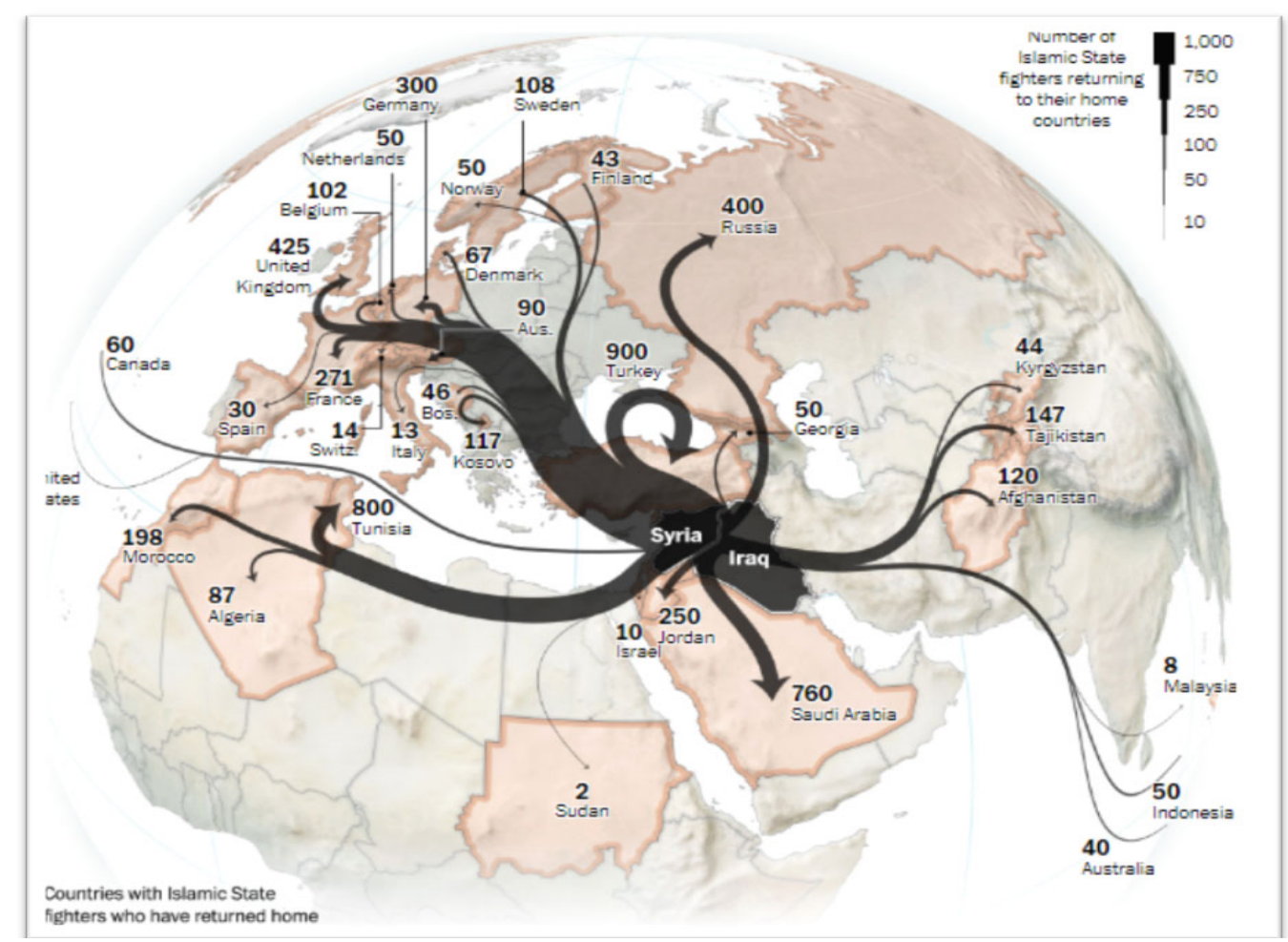

Figure 1. Numbers of Islamic State Fighters Returning to Their Home Countries Source: Meko, 2018.

\section{United States}

When considering the prosecution of returning foreign fighters, there are two relevant U.S. statutes that can be applied: 18 U.S.C §2339B (providing material support

\footnotetext{
89 "UN Global Counter-Terrorism Strategy | Counter-Terrorism Implementation Task Force." https:/www.un.org/counterterrorism/ctitf/en/un-global-counter-terrorism-strategy\#poa2. (Accessed 1 January 2019.)
} 
to a foreign terrorist organization), and 18 U.S.C $§ 2339 \mathrm{D}$ (receiving military-type training from a foreign terrorist organization). ${ }^{90}$ The examples provided below concern individuals who were prosecuted for breaking these laws.

A noteworthy case involved a Columbia University student of Bengali origin with American citizenship; court documents refer to him as "John Doe." What is interesting is the guilty plea of this foreign fighter. In November 2014, he pleaded guilty to violating both 18 U.S.C $\S 2339 B$ and 18 U.S.C $\S 2339 D$. Despite being brought to trial in 2014 , he was not sentenced until June 2018. A foreign fighter who participated in at least one battle, Doe was sentenced to two years and ten months of prison time, followed by ten years of supervised release. He was given this reduced sentence because he cooperated with the FBI before surrendering while still in Syria, providing information on ISIS activities. For his cooperation, Doe received a reduced sentence. The guideline for punishing criminals like Doe would have been a minimum of ten years in prison based on his violation of 18 U.S.C $\S 2339 D$, up to a maximum of 25 years. However, because the U.S. continues to struggle with the issue of returning foreign fighters, Doe received clemency.

As of June 2018, 163 federal cases had been filed involving American citizens who participated in some capacity with ISIS, and courts successfully convicted 115 of these individuals. ${ }^{91}$ A 2017 report by the Center on National Security at Fordham

\footnotetext{
${ }^{90}$ United States v. Doe, 323 F. Supp. 3d 368 (E.D.N.Y 2018).

${ }^{91}$ Center on National Security. Terrorism Database and Publications. Fordham Law School. https://www.centeronnationalsecurity.org/research/. Continually updated. (Accessed December 31, 2018.)
} 
University School of Law found that the average length of the sentences for these individuals was approximately 14 years. ${ }^{92}$

The United States has also successfully prosecuted associates of foreign fighters. Six Americans have been charged with violating 18 U.S.C §2339A (b) for aiding one individual, Ramo Abdullah Pazara, ${ }^{93}$ an ISIS foreign fighter who accepted money from associates in the United States. He was also known to be recruiting American citizens to join ISIS. Although Pazara was himself an American citizen, the United States could not prosecute him in absentia, unlike Belgium which can do so.

\section{Belgium}

Belgium has struggled with domestic terrorism in part because of the unusual number of its citizens that have travelled to fight with ISIS. Some 440 Belgian citizens have been documented as having some degree of activity with Islamic State or other foreign fighter groups in Syria, ${ }^{94}$ making it among the top countries whose citizens travel to fight in Syria. Peter Neumann, Director of the International Centre for the Study of Radicalization and Political Violence, wrote that the number of foreigners who have joined Sunni militant organizations in Syria and Iraq continues to rise, and that nearly 4,000 were residents or nationals of Western European countries. The five primary

\footnotetext{
${ }^{92}$ Karen Greenberg, ed., "The American Exception: Terrorism Prosecutions in the United States-The ISIS Cases, March 2014 to August 2017." https://static1.squarespace.com/static/ $55 \mathrm{dc} 76 \mathrm{f} 7 \mathrm{e} 4 \mathrm{~b} 013 \mathrm{c} 872183 \mathrm{fea} / \mathrm{t} / 59 \mathrm{cf9} 90 \mathrm{ae} 45 \mathrm{a} 7 \mathrm{c} 855 \mathrm{f} 673 \mathrm{bca} / 1506777101200 /$ The+American+Exception+917.pdf . (Accessed 23 February 2019.)

${ }^{93}$ Ramo Abdullah Pazara profile. https://www.counterextremism.com/extremists/abdullah-ramopazara

${ }^{94}$ De Guttry, Capone, and Paulussen, "Foreign Fighters," 393.
} 
countries are France (1,200), Germany (500-600), United Kingdom (500-600), Belgium (440), and the Netherlands (200-250)..$^{95}$

Belgium was the first country to criminalize the act of leaving for the purpose of fighting in another country. This provision made it a crime to encourage the public to commit terrorist activities, ${ }^{96}$ recruit others to commit a terrorist crime, ${ }^{97}$ provide training to commit a terrorist crime, ${ }^{98}$ and/or being part of training to commit a terrorist crime. ${ }^{99}$

Belgium came into the spotlight when 46 members of the terrorist group Sharia4Belgium were put on trial for fostering Islamist violence in Syria. Many were not present for the trial in Belgium, but the judge determined that they could be prosecuted in absentia because the court could not confirm that they had died in Syria. Without proof of death, the defendants were tried in absentia. The leader of Sharia4Belgium, Fouad Belkacem, was sentenced — in absentia - to 12 years in prison for recruitment and for inciting public terrorism. ${ }^{100}$

In another case, Abdelmajid Gharmaoui, a Belgian ISIS fighter, was identified in the video of a mass execution. Gharmaoui was the person who beheaded American aid

\footnotetext{
95 Peter R. Neumann, "Foreign Fighter Total in Syria/Iraq Now Exceeds 20,000; Surpasses Afghanistan Conflict in the 1980s," International Centre for the Study of Radicalization and Political Violence, 26 January 2015. http://icsr.info/2015/01/foreign-fighter-total-syriairaq-now-exceeds-20000surpasses-afghanistan-conflict-1980s/. Accessed 12 June 2015.

${ }^{96}$ Article 140bis of the Belgian Penal Code. http://counterterrorismethics.com/the-belgian-counterterrorism-landscape/. Section 4.1: Belgian Criminal Code. (Accessed 23 February 2019.)

${ }^{97}$ Article 140ter of the Belgian Penal Code.

${ }^{98}$ Article 140quater of the Belgian Penal Code.

${ }^{99}$ Article 140quinqies of the Belgian Penal Code.

${ }^{100}$ Robert Bartunek, “In Europe, Parents’ Dismay as Syria Jihad Lures Troubled Teens,” Reuters, 8 February 2015. http://www.reuters.com/article/2015/02/08/us-mideast-crisis-belgium-trialidUSKBN0LC0II20150208? feedType $=$ RSS\&feedName $=$ worldNews\&rpc $=69$.
} 
worker Peter Kassig. ${ }^{101}$ Gharmaoui was sentenced in absentia to five years, ${ }^{102}$ although the prosecution called for 10 years. Although Gharmaoui was sentenced in absentia, the video evidence was helpful for the prosecution because the video is unequivocal. Without that kind of evidence, courts have trouble prosecuting citizens for more than membership in a terrorist organization.

In a third case, Michael Delefortrie, a Catholic who converted to Islam in 2004, was recruited in 2009 by Fouad Belkacem to become a member of Sharia4Belgium. In 2013, Delefortrie travelled to Syria to fight with ISIS. The court prosecuted Delefortrie upon his return to Belgium, charging him with participating in a terrorist group. As of December 2018, Delefortrie continues to walk the streets a free man. Whether or not he violated international law has not been determined because it has been difficult to acquire evidentiary support that could tie him to a crime. In an interview with CNN, Delefortrie recognized that the activities he willingly participated in were associated with ISIS, and he said he supports its ideology. He did not express remorse for the tactics condoned by ISIS, and he admitted to arresting and supervising prisoners. ${ }^{103}$

\footnotetext{
101 John Hall, “Find Jihadi John's execution squad,” Daily Mail, November 18, 2014. https:/www.dailymail.co.uk/news/article-2839065/Find-Jihadi-John-s-execution-squad-Massive-manhuntinternational-ISIS-assassins-intensifies-family-French-scooter-salesman-converted-Catholicism-speakhorror.html . (Accessed 23 February 2019.)

102 "Sharia4Belgium, "Welke Straf Krijgt Elke Beklaagde?" ("What Punishment Does Each Defendant Receive?”). De Standaard, February 10, 2015. http://www.standaard.be/cnt/dmf20150210_01521286. (Accessed December 31, 2018.)

${ }^{103}$ Clarissa Ward, "From Altar Boy to ISIS Fighter," CNN, March 31, 2017. https://www.cnn.com/ interactive/2017/03/europe/isis-behind-the-mask/. (Accessed December 31, 2018.)
} 
Many of the crimes of the ISIS crimes were committed in makeshift facilities

built by ISIS, where torture, murder, and other serious crimes were committed. ${ }^{104}$

Delefortrie must have witnessed such activities, and he very likely possesses eyewitness

knowledge of these serious violations of international law. This knowledge is precisely

the kind of evidentiary support needed to bring foreign fighters accountable.

\section{France}

Based solely on numbers, France is home to the largest share of foreign fighters originally from Western Europe. More than 1,000 French citizens who travelled to join militant groups in Syria and Iraq. ${ }^{105}$

Among them is Flavien Moreau, who was prosecuted in France for travelling to Syria and participating in jihadist activity. The first French citizen to be prosecuted after returning home, Moreau received the maximum sentence of seven years. ${ }^{106}$ His prosecution set several precedents, as there were dozens more fighters still held in detention following their return to France. ${ }^{107}$

\footnotetext{
${ }^{104}$ UN Human Rights Council, "Out of Sight, Out of Mind: Deaths in Detention in Syria." Report of the Secretary-General, A/HRC/31/CRP.1, Appendix 1. February 3, 2016. https://www.ohchr.org/ Documents/HRBodies/HRCouncil/CoISyria/A-HRC-31-CRP1_en.pdf .

${ }^{105}$ Paulussen C., Entenmann E. (2016) National Responses in Select Western European Countries to the Foreign Fighter Phenomenon. In: de Guttry A., Capone F., Paulussen C. (eds) Foreign Fighters under International Law and Beyond. T.M.C. Asser Press, The Hague

${ }^{106}$ Jack Moore, "France: First Jihadist Sentenced for Fighting in Syria, Flavien Moreau Handed Seven Years," International Business Times, November 13, 2014. https://www.ibtimes.co.uk/france-first-jihadistsentenced-fighting-syria-flavien-moreau-handed-seven-years-1474688 (Accessed 23 February 2019.)

${ }^{107}$ Chine Labbé, "French Court Jails First Returning Syria Jihadi for Seven Years," Reuters, November 13, 2014. https://uk.reuters.com/article/uk-france-jihadi/french-court-jails-first-returning-syria-jihadi-forseven-years-idUKKCNOIX1WG20141113. (Accessed December 31, 2018.)
} 
Nicolas Moreau, his brother discussed above, was arrested in 2015 after returning from fighting in Syria. Nicolas was sentenced to ten years in prison by the French court. Both brothers were born in South Korea and adopted by French parents when they were four. Both were radicalized and converted to Islam while serving time in a French prison for unrelated crimes. This time around, Nicholas threatened to return to fighting if the French court handed him a harsh sentence. ${ }^{108}$

Returning jihadists continue to pose a threat to France. It makes the challenges of arresting and prosecuting foreign fighters even more difficult when those who are convicted pledge to wreak further havoc after their release from prison.

\section{Denmark}

The Danish courts have chosen to deal with the return of foreign fighters in a different way. The so-called "Aarhus model" takes the view that returning Danish citizens who are foreign fighters in other countries are naïve and in need of rehabilitation. ${ }^{109}$ This approach has not stopped Denmark from prosecuting those they believe are an imminent national security risk.

In March 2017, a defendant was found guilty of violating the Danish Criminal Code by being recruited to commit acts deemed criminal by Section 114 and Section 114a of the Danish Criminal Code. When the defendant entered Syria, he was recruited

\footnotetext{
${ }^{108}$ France 24, "French Jihadist Back From Syria Sentenced to 10 Years in Jail". February 1, 2017. https://www.france24.com/en/20170102-france-jihadist-syria-moreau-sentenced-jail.

${ }^{109}$ Robin Simcox, “When ISIS Fighters Return Home,” Heritage Foundation, March 21, 2018. https://www.heritage.org/terrorism/commentary/when-isis-fighters-return-home. (Accessed 23 February 2019.)
} 
by Islamic State and chose to be trained in combat and the use of weapons. ${ }^{110}$ When an appeal was entered because the court sought to revoke the defendant's Danish citizenship (he was also a Turkish national), the court affirmed that the defendant had violated several components of Section 114c (1) of the Criminal Code by committing acts such as fighting for Islamic State in Syria; for having entered Syria with the intent of joining the organization for which he had trained in the use of arms; and that his actions originated from radicalized attitudes that he expressed in letters and confirmed in testimony. The Danish Supreme Court's majority ruling noted that the defendant's time with Islamic State had been of limited duration. ${ }^{111}$ The court did not accept the prosecution's contention that the defendant should be deprived of his Danish nationality (pursuant to Section 8b, Subsection 2 of the Danish Act on Nationality) and be expelled permanently (pursuant to section 22 (6) of the Aliens Act). Instead, the court sentenced the defendant to six years in prison, and he was expelled from Denmark permanently.

\section{Summary of Decentralized Prosecutions}

The examples given above portray typical challenges facing countries where foreign fighters have returned to their original home. With the challenges come the complications of pairing individuals with crimes they are alleged to have committed in

\footnotetext{
110 "Danish/Turkish citizen, who had been recruited by the Islamic State in Syria, sentenced to 6 years' imprisonment, deprived his Danish nationality and expelled from the country forever.," Domstol, 21 March 2017. https://www.domstol.dk/oestrelandsret/nyheder/domsresumeer/Pages/Dansktyrkiskstatsborger, derhavdeladetsighverveafIslamiskStatiSyrien,id $\% \mathrm{C3} \% \mathrm{~B} 8 \mathrm{mtf} \% \mathrm{C} 3 \% \mathrm{~A} 6$ ngseli6\%C3\%A5r,frakendtsindansk eindf $\%$ C3\%B8dsretogudvistafl.aspx Translated to English. Accessed December 25, 2018.

${ }^{111}$ On 7 June 2017, the Process Grant Board issued an accused license to appeal to the Supreme Court of a ruling of the Eastern High Court on 31 March 2017. Domstol, 6 August 2017. https://www.domstol.dk/Procesbevillingsnaevnet/nyheder/Appeltilladelser/Pages/Begr\%C3\%A6nset.aspx
} 
the Syrian civil war. While social media has helped some countries gather evidence enabling them to prosecute returning foreign fighters who are native citizens, the system itself remains decentralized, which only adds to the inefficiencies and inability to curb the potential threats posed by these foreign fighters. Furthermore, returning foreign fighters all over the world can bear testimony to the behaviors and crimes committed by ISIS. But without evidence that returning foreign fighters have committed crimes, these detained fighters are not obligated to provide information about those who participated in war crimes, crimes against humanity, genocide, and more.

The international community should pay special notice to the advice of Kurdish forces in northern Syria. The Kurds have demanded that foreign fighters face trial in the country of their original residence. ${ }^{112}$ This demand comes as the result of overwhelming costs facing the Kurds as they try provide adequate detention facilities for some 500 foreign citizens captured in the Syrian civil war. To house and feed these foreign fighters is a burden they cannot support. In addition, Human Rights Watch estimates some 2,000 women and children are also under Kurdish supervision. ${ }^{113}$

This crisis has come to a head because many countries have so far refused to repatriate their citizens who have been captured. In view of the Kurdish demand to remove detainees from their supervision, combined with other countries' refusal to allow the return of their citizens who are foreign fighters, the world must identify other mechanisms for prosecuting these foreign fighters. Currently, there are limited

\footnotetext{
112 Bethan McKernan, "Foreign ISIS Fighters Must Face Trial on Home Soil, Kurds Say," Guardian, September 24, 2018. https:/www.theguardian.com/world/2018/sep/24/foreign-isis-fighters-must-face-trialon-home-soil-kurds-say. (Accessed 14 August 2018.)

${ }^{113}$ McKernan, "Foreign ISIS Fighters."
} 
mechanisms for such prosecution — all of them inadequate and inappropriate for crimes committed in the Syrian civil war.

A key question is: how should a foreign fighter, who participated in the ethnic cleansing of a Syrian town, be prosecuted if he/she is captured in their original country of residence? Prior cases suggest these individuals could be prosecuted for violations of crimes that are part of domestic law. But are sentences based on domestic laws appropriate for someone who may have participated in ethnic cleansing, or rape, or beheading, or executions in illegal detention facilities? I believe it is insufficient to utilize domestic laws to render justice for international crimes.

How should the international community hold these foreign fighters accountable for the violations they have committed? The International Criminal Court cannot be the appropriate venue for prosecuting foreign fighters because Syria is not a state party to the Rome Statute. To resolve this problem, the international community must come together as a cohesive force and establish a mechanism for detaining and prosecuting all foreign fighters who violate international law in the Syrian civil war. 


\section{Chapter VI}

\section{Extraordinary Measures for Extraordinary Circumstances}

Since the twentieth century, a small number of international courts have been established. One path to creating an international court through the United Nations is a time-consuming approach based on treaties among states directly or indirectly involved with a conflict. A second path is by a resolution through the UNSC. The latter is responsible for such courts as the International Criminal Tribunal for the former Yugoslavia (ICTY), the International Criminal Tribunal for Rwanda (ICTR), and the Special Tribunal for Lebanon. Both ICTY and ICTR were established by invoking Chapter VII of the United Nations Charter. ${ }^{14}$

I suggest that an international tribunal for crimes committed by foreign fighters in the Syrian civil war should be established, with these three courts serving as a frame of reference for an International Tribunal for the Prosecution of Foreign Fighters Responsible for Serious Violations of International Humanitarian Law and International Human Rights Law Committed in the Territory of the Syrian Arab Republic since 2011.

\section{History of Three Courts}

In 1993 and 1994, the UNSC established international tribunals to prosecute individuals involved in specific conflicts who committed violations of international

\footnotetext{
${ }^{114}$ United Nations Charter, Chapter VII. http://www.un.org/en/sections/un-charter/chapter-vii/. (Accessed 24 February 2019.)
} 
humanitarian law. In 1993, a court was established to bring to justice perpetrators of crimes committed in the territory of the former Yugoslavia since 1991. Another international court was established to prosecute violations of IHL committed in Rwanda. Also, at the request of Lebanon following the assassination of the Lebanese prime minister, a court was establishing seeking those responsible for the attack. These tribunals are helpful examples for understanding how to establish an international tribunal in response to the Syrian civil war.

International Criminal Tribunal for the Former Yugoslavia (ICTY)

The ICTY was born out of the difficult events that followed the collapse of the fragile Yugoslavian state in early 1993. At the time, Yugoslavia was home to many ethnic groups, including Serbians, Bosnians, Croats, Slovenes, and others. When the ethnic and religious groups in the country began to declare their independence, the state retaliated in effort to stunt secession demands. This resulted in grave crimes committed in violation of the Geneva Conventions. During the ensuing war between the government and secessionists, more than 100,00 people were killed and approximately 4 million were displaced. ${ }^{115}$

In May 1993, the UNSC passed Resolution 827 establishing the International Tribunal for the Violations of International Humanitarian Law that occurred in Bosnia and Herzegovina. The court had jurisdiction over "Genocide, Crimes against Humanity, Violations of the Laws or Customs of War, and Grave Breaches of the Geneva

\footnotetext{
${ }^{115}$ International Center for Transitional Justice. https://www.ictj.org/sites/default/files/ICTJFormerYugoslavia-Justice-Facts-2009-English.pdf . (Accessed December 27, 2018.)
} 
Conventions."116 The court successfully sentenced 90 of 161 indicted individuals. No fugitives remain outstanding as a result of the work of this court. ${ }^{117}$

The ICTY came under criticism for numerous shortcomings. Some scholars noted that despite being established in 1993, the court did not stop mass killings or the genocide that took place in Srebrenica in $1995 .{ }^{118}$ Other criticisms stem from an inability to persuade the local audience that the court was needed in order to serve justice. Marko Milanovic, an international law scholar and critic, believes the ICTY is a failure for exactly that reason.. ${ }^{119}$ Nevertheless, Milanovic believes the ICTY has made an impact on international law. He views the ICTY as a significant inspiration for the establishment of an international criminal court where needed. ${ }^{120}$

International Criminal Tribunal for Rwanda (ICTR)

A year after the ICTY was founded, the ICTR was established following horrendous events that took place in Rwanda. Ethnic tensions between the Hutu and Tutsi tribes exploded into genocide, with almost one million Tutsi murdered by Hutu in three

${ }^{116}$ UN Security Council, Resolution S/RES/827 (1993) https://undocs.org/S/RES/827(1993).

${ }^{117}$ UN International Residual Mechanism for Criminal Tribunals. http://www.icty.org/node/9590 . (Accessed December 27, 2018.)

${ }^{118}$ Marko Milanovic. "The Impact of the ICTY on the Former Yugoslavia: An Anticipatory Postmortem.” American Journal of International Law 110, no. 2 (2016): 233-259.

${ }^{119}$ Marko Milanovic. "Courting Failure: When are International Criminal Courts Likely to Be Believed by Local Audiences?” In K.J. Heller, F. Megret, S. Nouwen, J. Ohlin, and D. Robinson, eds., The Oxford Handbook of International Criminal Law (Oxford: Oxford University Press, forthcoming ). Article available at https://ssrn.com/abstract=2887090. (Accessed 24 February 2019.)

\footnotetext{
${ }^{120}$ Marko Milanovic, "The Impact of the ICTY on the Former Yugoslavia: An Anticipatory Postmortem," American Journal of International Law 110 (2016): 233-259.
} 
months. ${ }^{121}$ The systematic campaign began with a call to exterminate Tutsis, bringing out Hutu tribesmen brandishing knives, machetes, spears, and clubs spiked with nails, who began to commit genocide. ${ }^{122}$

The international community repeatedly expressed outrage at the events unfolding in Rwanda, and as a result, the UNSC invoked Chapter VII of the UN Charter and passed Resolution 955 on November 8, 1994, establishing the ICTR. ${ }^{123}$ The tribunal was established for the purpose of prosecuting persons responsible for genocide and other serious violations of international humanitarian law committed in Rwanda, and for rendering justice against Rwandan citizens responsible for genocide and other such violations committed in the territory and neighboring States, between 1 January 1994 and 31 December 1994.

This tribunal produced 62 indictments among 93 individuals, including highranking military and government personnel, politicians, businessmen, religious figures, those belonging to militias, and individuals responsible for the incitement of genocide through media. ${ }^{124}$ Another interesting success was that this court was the first of its kind to prosecute using the word "genocide" as defined in the 1948 in the Geneva Convention, and defining rape as a crime utilized in the commission of genocide. ${ }^{125}$

${ }^{121}$ BBC News. "Black Earth Rising: The Rwandan Genocide and its Aftermath," September 10, 2018. https://www.bbc.com/news/world-africa-45447840.

${ }^{122}$ Samantha Power, A Problem from Hell: America and the Age of Genocide (New York: Basic Books, 2013), 334..

${ }^{123}$ UN Security Council, Resolution S/RES/955. November 8, 1994. https://undocs.org/S/RES/955.

${ }^{124}$ United Nations International Residual Mechanism for Criminal Tribunals (IRMCT), “The ICTR in Brief.” http://unictr.irmct.org/en/tribunal. (Accessed 24 February 2019.)

${ }^{125}$ UN IRMCT. 
It should be noted that the United States and the world community did not do as much as it could and should have done to limit what occurred in Rwanda. It is difficult to justify such inaction, but many believe the world simply did not fully understand the depth and speed with which Rwanda and adjoining areas were engulfed by this terror. The United States, under President Bill Clinton, expressed remorse for the country's delay in responding to the atrocities committed during the 100-day massacre of Tutsi people, and followed up years later with a personal visit. ${ }^{126}$

Special Tribunal for Lebanon

The Special Tribunal for Lebanon (STL) set a precedent when it was established following the assassination of the Lebanon's Prime Minister Rafik Hariri. The tribunalthe first to cover terrorism as a crime-was charged with finding those responsible for the attack. $^{127}$

The STL's decision regarding acts of terrorism was highly controversial. For one, this was the first time an international court was established that had jurisdiction over acts of terrorism and the act of spreading terrorism. ${ }^{128}$ The STL was given jurisdiction over the acts of terrorism because the crime was already present in the Lebanese Code.

\footnotetext{
${ }^{126}$ James Bennet, "Clinton Declares U.S., With World, Failed Rwandans” New York Times, March 26, 1998: A6, A12.

${ }^{127}$ Statute of the Special Tribunal for Lebanon, Resolution S/RES/1757. 31 January 2007. https:/www.stl-tsl.org/en/documents/statute-of-the-tribunal/223-statute-of-the-special-tribunal-for-lebanon. (Accessed 24 February 2019.)

${ }^{128}$ Michael P. Scharf, "Special Tribunal for Lebanon Issues Landmark Ruling on Definition of Terrorism and Modes of Participation," American Society of International Law, Insights (15) March 4, 2011. https://www.asil.org/insights/ volume/15/issue/6/special-tribunal-lebanon-issues-landmark-rulingdefinition-terrorism-and-modes-of-participation. (Accessed 24 February 2019.)
} 
The STL developed international law's first clear definition of what constituted an act of terrorism. The STL found that acts of terrorism have three elements: (i) perpetration of a criminal act (such as murder, kidnapping, hostage-taking, arson), or threatening such an act; (ii) intent to spread fear among the population (which generally entails the creation of public danger), or directly or indirectly coercing a national or international authority to take or refrain from taking some action; and (iii) when an act has a transnational element. ${ }^{129}$

What assisted the STL tribunal was the investigative mechanism of the United Nations International Independent Investigation Commission (UNIIIC), which was pivotal for prosecutors in the court. ${ }^{130}$ It provided research assistance and knowledge that often became the foundation for holding individuals accountable for the crimes that fell under the jurisdiction of the STL.

These three international tribunals stand as pillars for the international community, providing guidance and inspiration during the challenges encountered while bringing justice to Syrians and to the world. These three tribunals are excellent examples of how to proceed in the next struggle to prosecute non-state entities and foreign fighters who are alleged to have committed atrocities.

\footnotetext{
${ }^{129}$ Scharf, "Special Tribunal for Lebanon," 172.

${ }^{130}$ David Tolbert, “Introduction: A Very Special Tribunal.” Chapter 1. In Amal Alamuddin, Nidal Nabil Jurdi, and David Tolbert, eds., The Special Tribunal for Lebanon: Law and Practice (Oxford: Oxford University Press, 2014).
} 


\section{Learning from Past Tribunals}

Because several violations to international law were committed in the twentieth century, the international community looked to establish a court that could have jurisdiction over such violations. This is one reason why the ICC was established. However, the deficiency of the ICC remains that only state parties to the Rome Statute can petition the ICC. The issue of prosecuting foreign fighters who participated in the Syrian civil war further exacerbates this deficiency. Furthermore, the ICC is known to require an extended period of time for review of each case prior to administering the trial. Moreover, decentralization of prosecutions in no way seeks to stop prosecution of continuing threats at the global level. But, for all these reasons, an alternative approach to current practice is needed.

The strong will of nations to bring violators of humanitarian and human rights law to justice sends a strong signal to the world that that such activity cannot be tolerated. A concerted effort to establish a decentralized tribunals, like those described earlier, is needed. The world is now accountable for aiding victims when a terrorist entity uses gross measures to execute violations of IHL or IHRL. Hindsight helps us avoid pitfalls that occurred in past tribunals, and understanding the earlier shortcomings of past tribunals allows us to cover bases that could threaten the integrity of the court.

The humanitarian crisis in Syria shares many similarities with the atrocities committed in Rwanda and Yugoslavia. The world and the United Nations cannot be paralyzed or allowed to abandon methods that could prevent future violations of international law to go unchallenged. 
There is something we can do. I propose establishing an International Tribunal for the Prosecution of Foreign Fighters Responsible for Serious Violations of International Humanitarian Law and International Human Rights Law Committed in the Territory of the Syrian Arab Republic since 2011. I believe taking this step is the best viable option for holding foreign fighters accountable and for bringing at least some justice to the victims of the Syrian civil war. 


\section{Chapter VII}

\section{A New International Tribunal}

Viable approaches to holding foreign fighters accountable for crimes committed during the Syrian civil war have not been available since such fighters became apparent in the country. Decentralized prosecution of fighters who return to their original country of residence is not adequate to address violations committed by foreign fighters.

The most plausible approach is to create a mechanism to enforce international law by establishing an international tribunal through the United National Security Council. Many criticisms and concerns may arise at the thought of creating yet another international tribunal, but the bigger picture mandates implementation of such a tribunal as the best option. The IIIM and HRC have monitored and extensively documented the violations committed. Their reports are extremely useful and could be utilized by an international court that has jurisdiction over violations committed in the Syrian civil war. Therefore, an International Tribunal for the Prosecution of Foreign Fighters Responsible for Serious Violations of International Humanitarian Law or International Human Rights law Committed in the Territory of the Syrian Arab Republic since 2011 must be proposed, voted for, and established by the UN Security Council.

Of the 193 members of the United Nations, more than 100 are the home countries of foreign fighters in Syria. ${ }^{131}$ In order to establish an international tribunal, a UN

\footnotetext{
${ }^{131}$ UN Security Council Counter-Terrorism Committee, "Foreign Terrorist Fighters." https:/www.un.org/sc/ctc/focus-areas/foreign-terrorist-fighters/. (Accessed 24 February 2019.)
} 
Security Council resolution must survive without any veto from United States, England,

France, Russia, and China. Therefore it is paramount to construct a resolution that establishes a court with jurisdiction over only foreign fighters, specifically those belonging to recognized terrorist organizations in the Syrian civil war.

Through the United Nations, countries have expressed difficultly with prosecuting their citizens who have decided to become foreign fighters. ${ }^{132}$ The time has come for an international tribunal that unites existing UN resolutions into one. ${ }^{133}$ Dissatisfaction by some members vis-à-vis parties in the conflict escaping accountability might mistakenly suggest that a comprehensive tribunal is the only viable approach for addressing violations committed during the Syrian civil war.

A comprehensive tribunal may seem ideal, but I believe it is implausible. Arguments against an international tribunal would likely include historical associations of a new court with the actions of past courts. The tribunals in Yugoslavia and Rwanda were intensely criticized for their inefficiencies, and it is likely that a new tribunal similar to the one I am proposing would undergo intense scrutiny. Criticisms are acceptable, but if critics like Milanovic recognize the potential benefits and opportunities that such a tribunal could bring, it could support rather than denigrate the establishing of a new

\footnotetext{
${ }^{132}$ UN S/Res/2178 (2014): Addressing the Growing Issue of Foreign Terrorist Fighters, September 24, 2014. http://www.un.org/ga/search/view_doc.asp?symbol=S/RES/2178\%20\%282014\%29 .

${ }^{133}$ Including these several resolutions: UN S/2015/123:Challenges in Prosecutions Related to Foreign Terrorist Fighters. February 23, 2015. https:/www.un.org/sc/ctc/wp-content/uploads/2015/09/ S_2015_123_EN.pdf; UN S/2015/338: Implementation of Security Council Resolution 2178 (2014) By States Affected By Foreign Terrorist Fighters, May 14, 2015. https://www.un.org/sc/ctc/wpcontent/uploads/2015/06/N1514129_EN.pdf; UN S/2015/683: Implementation of Security Council Resolution 2178 (2014) By States Affected By Foreign Terrorist Fighters, September 2, 2015. https:/www.un.org/sc/ctc/wp-content/uploads/2015/09/N1527297_EN.pdf; and UN S/2015/975: Implementation of Security Council Resolution 2178 (2014) By States Affected By Foreign Terrorist Fighters - Third Report, December 29, 2015. https://www.un.org/sc/ctc/wp-content/uploads/2016/02/ N1545987_EN.pdf.
} 
tribunal. During the development of a new court, earlier criticisms made about past tribunals could be taken as opportunities to learn from past mistakes.

The geopolitics of the Syrian civil war hamper international efforts to prosecute those who have violated international law. Despite moral reservations against prosecuting some groups and excluding others, no viable path yet exists for holding accountable all alleged violators of international law. The current framework allows the Syrian government, including President Bashar Al-Assad, to remain free from being held accountable by the UN because any resolution brought forward to hold Syria or Al-Assad responsible will be struck down by a Russian or possibly a Chinese veto.

Russia is Syria's most important ally. Without the Russian veto, the UNSC could have implemented several resolutions that could have led to Al-Assad experiencing a fate similar to that of Muammar Ghaddafi. ${ }^{134}$ On a dozen occasions, Russia utilized its veto power in the UNSC to reject any resolution that would jeopardize Syrian sovereignty. ${ }^{135}$ Some argue that another hurdle, if a resolution were to target only specific foreign fighters, is that the United States would veto such a resolution. I suggest that the United Stated has operated pragmatically since President Obama's administration. The United States has retracted its position on regime change in Syria, an indication that Al-Assad would be allowed to continue his administration. ${ }^{136}$ The United States would stand to

\footnotetext{
${ }^{134}$ The UNSC and NATO collaborated in resolutions that led to airstrikes that subsequently brought about the downfall of Ghaddafi, former leader of Libya.

${ }^{135}$ BBC News, "Syria: Does Russia Always Use a Veto at the UN Security Council?" April 16, 2018. https://www.bbc.com/news/world-43781954.

${ }^{136}$ Patrick Reevell, “US Not Seeking 'Regime Change' in Syria, John Kerry Says After Meeting With Russian President,” ABC News, 15 December 2015.. https://abcnews.go.com/International/john-kerrymeets-russian-president-vladimir-putin-seek/story?id=35782171 (Accessed 17 February 2019.)
} 
benefit from a concerted international effort to address threats posed by foreign fighters, so it is likely to vote "yes" for a tribunal that provides a more viable way to bring justice. Another indication that Russia and the United States would support a resolution for an international tribunal can be found by reviewing their past cooperative efforts on counterterrorism, which Russia has endured just like the United States and the European Union. Russia has cooperated with the United States several times in Syria and elsewhere to address mutual threats. ${ }^{137}$

One of the most serious challenges to an international tribunal is evidentiary support tying foreign fighters to specific crimes against international law. Monitoring groups report repeated challenges when attempting to access ISIS-held territories. Such challenges lead some to believe an international tribunal will be unable to acquire sufficient evidence to corroborate guilt.

This may be why many returning foreign fighters are instead prosecuted for membership in a terrorist organization. But I believe it is critical that the most serious crimes take precedence over domestic laws that criminalize only membership in a terrorist organization. Some violations to international law, such as ethnic cleansing and crimes against humanity, are unquestionably more serious than membership.

Creating an international tribunal that enables countries to transfer foreign fighters detained anywhere in the world to an approved court would be costly. Despite the cost, however, I believe the idea should stand, if for no other reason than the ability to crossexamine foreign fighters. Cross-examination will enable prosecutors, the court, and the

\footnotetext{
${ }^{137}$ George Beebe, "Thank You for Sharing: A Rare Counterterror Win for U.S.-Russian Relations," National Interest, December 19, 2017. https://nationalinterest.org/feature/thank-you-sharing-rarecounterterror-win-us-russian-23720.
} 
world to elicit more information regarding violations committed by foreign fighter

groups. This information is priceless, since information on battalions, commands, and leadership is largely unknown. 


\section{Chapter VIII}

\section{Dénouement}

My proposal, to establish a new tribunal under the aegis of the UN Security Council, seeks a plausible avenue whereby world powers could agree upon an international court that would target mutual threats. Both the United States and Russia have fought foreign fighters in Syria, and dealt with organized groups that carry out terrorist attacks: JN, ISIS, and others. Together, the United States and Russia are in the best possible position to develop and implement a tribunal that would hold foreign fighters accountable.

Past tribunals have demonstrated that an international tribunal is the best solution when handling severe violations of international law. Even though this option is costly, that is not a sufficient reason to dismiss establishing such a tribunal. Expressions of unity within the international community in the face of international terrorism must be taken advantage of through concerted efforts to minimize the threats before they evolve into an unmanageable situation. Russia and the United States have shared intelligence and participated together in military efforts to attack Islamic State and other extremist groups in Syria. But forcibly returning foreign fighters so they can be prosecuted in their country of residence has not produced satisfactory results either.

To suggest that one country would veto a UN resolution because it would not further that country's national interest in the Middle East is not the same as one country vetoing a resolution because it is detrimental to its ally in the region. Russia has voted 
with the United States in numerous resolutions involving the Syrian civil war. A UNSC resolution that establishes a court that brings alleged terrorist criminals to stand trial protects both countries and the world from threats that could ensue if instead foreign fighters went home and continued a campaign of terrorism - as ISIS strongly promotes its fighters to do.

Although the Rwandan and Yugoslavian tribunals have been criticized for their inefficiencies, it is not reasonable to suggest that they were useless. Both courts brought severe criminals to stand trial for crimes committed. Their actions safeguarded the integrity of international law, and they did a credible job of bringing justice in the name of war victims. Therefore, suggesting that not all crimes or criminals should be included in the international tribunal is not a sufficient argument against establishing such a tribunal, and it without merit.

Finally, all the variables needed to establish this tribunal are present:

- a strong political will to establish, thus bypassing a possible Russian or American veto;

- benefits that justify the costs;

- an international tribunal that is more effective at prosecuting serious crimes than prosecutions simply on the basis of membership in an organization;

- evidentiary support that becomes available during cross-examination; and

- wide-ranging and persuasive reports from the International Impartial And Independent Mechanism To Assist In The Investigation And Prosecution Of Persons Responsible For The Most Serious Crimes Under 
International Law Committed In The Syrian Arab Republic Since March 2011, and from the Independent International Commission of Inquiry on the Syrian Arab Republic.

All of these variables make a strong and persuasive case for this most plausible approach to addressing the challenge of holding foreign fighters accountable for crimes committed during the Syrian civil war: my proposal for an International Tribunal for the Prosecution of Foreign Fighters Responsible for Serious Violations of International Humanitarian Law or International Human Rights law Committed in the Territory of the Syrian Arab Republic since 2011, which can be found in the next chapter. 


\section{Chapter IX}

A MODEL: A Proposed Resolution

\section{Resolution \#\#\#\# (20XX) $)^{138}$}

The United Nations Security Council,

Reaffirming its Resolution 2178 (2015) of 24 September 2014 and all subsequent relevant Resolutions;

Recalling Resolution 2178 (2014) and the definition of foreign terrorist fighters, and expressing grave concern over the acute and growing threat posed by foreign terrorist fighters returning or relocating, particularly from conflict zones, to their countries of origin or nationality, or to third countries;

Recalling paragraph 1 of its Resolution 2254 (2015) of 18 December 2015, in which it condemns the violent extremism that can be conducive to terrorism, sectarian violence, and the commission of terrorist acts by foreign terrorist fighters, and demands that all foreign terrorist fighters disarm and cease all terrorist acts and participation in armed conflict;

Reaffirming that terrorism poses a threat to international peace and security and that countering this threat requires collective efforts on national, regional, and

\footnotetext{
${ }^{138}$ This Draft Resolution is the creation of Peter Cephas Dahabreh. The language and paragraphs are text taken from UNSC Res 808, 2178, and 2254, and blended to create this proposed Resolution. I have constructed the paragraphs loosely to illustrate that such a Resolution as this could be a template for an actual resolution.
} 
international levels on the basis of respect for international law and the Charter of the United Nations;

Reaffirming its commitment to sovereignty, territorial integrity, and political independence of all States in accordance with the Charter of the United Nations;

Reaffirms that those responsible for committing, or otherwise responsible for terrorist acts and violations of international humanitarian law, or violations or abuses of human rights in this context, must be held accountable;

Reaffirms that foreign terrorist fighters and those who finance or otherwise facilitate their travel and subsequent activities may be eligible for inclusion on the ISIL (Da'esh) Al-Qaida Sanctions List maintained by the Committee pursuant to Resolutions 1267 (1999), 1989 (2011), and 2253 (2015), where they participate in the financing, planning, facilitating, preparing, or perpetrating of acts or activities by, in conjunction with, under the name of, on behalf of, or in support of, supplying, selling, or transferring arms and related materiel to, or recruiting for, or otherwise supporting acts or activities of Al-Qaida, ISIL, or any cell, affiliate, splinter group, or derivative thereof, and calls upon States to propose such foreign terrorist fighters and those who facilitate or finance their travel and subsequent activities for possible designation;

Recalling further its Resolution 2396 (2017) of 21 December 2017, in which it calls upon Member States to assess and investigate individuals they have reasonable grounds to believe are terrorists, including suspected foreign terrorist fighters, and distinguish them from other individuals, including their accompanying family members who may not have been engaged in foreign terrorist fighter-related offenses, including by employing evidence-based risk assessments, screening procedures, and the collection and 
analysis of travel data, in accordance with domestic and international law, including international human rights and humanitarian law, as applicable, without resorting to profiling based on any discriminatory ground prohibited by international law;

Recalls its decision, in Resolution 1373 (2001), that all Member States shall ensure that any person who participates in the financing, planning, preparation, or perpetration of terrorist acts or in support of terrorist acts, is brought to justice, and further recalls its decision that all States shall ensure that their domestic laws and regulations establish serious criminal offenses sufficient to provide the ability to prosecute and to penalize the activities described in paragraph 6 of Resolution 2178 in a manner reflecting the seriousness of the offense against humanity, and outrages upon human dignity.

1. Determining that this situation constitutes a threat to international peace and security,

2. Determined to put an end to such crimes and to take effective measures to bring to justice the persons responsible for them,

3. Convinced that in the particular circumstances of the Syrian Arab Republic the establishment of an international tribunal would enable this aim to be achieved and would contribute to the restoration and maintenance of peace,

4. Noting further the report of the Independent International Commission of Inquiry on the Syrian Arab Republic and the International, Impartial and Independent Mechanism to Assist in the Investigation and Prosecution of Persons Responsible for the Most Serious Crimes under International Law Committed in the Syrian Arab Republic since March 2011 are credible sources for the further investigation and indictment of 
perpetrators of crimes committed by foreign fighters in the territory of the Syrian Arab Republic since 2011;

5. Decide that an international tribunal shall be established for the Prosecution of Foreign Fighters Responsible for Serious Violations of International Humanitarian Law and International Human Rights Law Committed in the Territory of the Syrian Arab Republic since 2011;

6. Requests the Secretary-General to submit for consideration by the Council at the earliest possible date, and if possible no later than 60 days after the adoption of the present resolution, a report on all aspects of this matter, including specific proposals and, where appropriate, options for the effective and expeditious implementation of the decision contained in paragraph 1 above, taking into account suggestions put forward in this regard by Member States;

7. Decides to remain actively seized of the matter.

Adopted by the Security Council at its XXXXXth meeting, on XX/XX/XXXX. 


\section{Appendix 1}

\section{Relevant Paragraphs Detailing Crimes Against Humanity}

ISIS subjected prisoners to serious abuses, including torture and summary executions. Detainees were frequently executed after unauthorized courts issued a death sentence. ISIS has committed the crimes against humanity of murder and torture, and war crimes.

Relevant Paragraphs: 5, 76, 103,104.

Paragraph 5. As armed groups and terrorist organizations have come in control of territory, they have also held prisoners under the most brutal conditions. The socalled Islamic State of Iraq and Al-Sham (ISIS), is known to illegally hold a large, unknown number of detainees for extended periods in multiple locations, subjecting many to torture and routinely conducting summary executions. Jabhat Al-Nusra and anti-Government armed groups control places of detention, holding Government soldiers as well as civilians. The torture and deaths of detainees have been recorded in some of these facilities.

Paragraph 76. The killing of detainees was documented as occurring in an ISIS detention facility in or near Jarablus in 2014 and 2015. In 2014, a former detainee described ISIS fighters severely torturing civilians held inside the centre. He witnessed a 27year-old man being taken out of his cell, and screaming while he was beaten with 
a metal bar. When he was brought into the cell, the man was foaming from the mouth. When his cellmates called for medical attention, the guards said "let him suffocate". The man died shortly afterwards. Another interviewee, also held in a detention facility in Jarablus in September 2015, described three detainees being shot in front of him by ISIS guards.

Paragraph 103. ISIS is responsible for murder, torture and other forms of ill-treatment, outrages upon personal dignity and summary executions occurring in detention facilities run by the group, in violation of applicable international humanitarian law and international human rights law. Executions of persons detained and brought before illicit courts amount to murder or summary executions, constituting war crimes. The group has also committed the war crime of torture. Its unauthorized mock trials furthermore deprive victims of basic due process guarantees in violation of international humanitarian law and international human rights law.

Paragraph 104. This conduct, when forming part of a widespread attack against a civilian population, constitutes the crimes against humanity of murder and torture. 


\section{Bibliography}

Akour, Omar. "New Video Purports to Show Jordanian Pilot Burned to Death by IS Militants." Christian Science Monitor, 3 February 2015.

https://www.csmonitor.com/ World/Latest-News-Wires/2015/0203/New-videopurports-to-show-Jordanian-pilot-burned-to-death-by-IS-militants. (Accessed 22 February 2019).

Baczko, Adam, Gilles Dorronsoro, and Arthur Quesnay. Civil War in Syria: Mobilization and Competing Social Orders, Problems of International Politics. Cambridge: Cambridge University Press, 2018.

Baker, Aryn. "How ISIS is Recruiting Women from Around the World." Time Magazine, September 6, 2014. http://time.com/3276567/how-isis-is-recruiting-women-fromaround-the-world/. (Accessed 20 February 2019.)

Bakker E., and M. Singleton. "Foreign Fighters in the Syria and Iraq Conflict: Statistics and Characteristics of a Rapidly Growing Phenomenon." In: A. de Guttry, F. Capone, and C. Paulussen (eds). Foreign Fighters Under International Law and Beyond. The Hague: T.M.C. Asser Press, 2016.

Ball, James. "Obama Issues Syria Red Line Warning On Chemical Weapons.”

Washington Post, August 20, 2012. https://www.washingtonpost.com/world/ national-security/obama-issues-syria-red-line-warning-on-chemicalweapons/2012/08/20/ ba5d26ec-eaf7-11e1-b811-09036bcb182b_story.html? utm_term $=.1 \mathrm{c} 4967 \mathrm{~b} 9 \mathrm{ca5e}$. (Accessed 20 February 2019.)

Bartunek, Robert. "In Europe, Parents' Dismay as Syria Jihad Lures Troubled Teens." Reuters, 8 February 2015. http://www.reuters.com/article/2015/02/08/us-mideastcrisis-belgium-trial-idUSKBN0LC0II20150208?feedType=RSS\&feedName $=$ worldNews\&rpc=69. (Accessed 23 February 2018.)

BBC News. "Black Earth Rising: The Rwandan Genocide and its Aftermath." September 10, 2018. https://www.bbc.com/news/world-africa-45447840.

BBC News. "Ratko Mladic Jailed For Life Over Bosnia War Genocide." November 22, 2017. https://www.bbc.com/news/world-europe-42080090. (Accessed 20 February 2019.)

BBC News. "Syria: Does Russia Always Use a Veto at the UN Security Council?" April 16, 2018. https://www.bbc.com/news/world-43781954 . (Accessed 16 June 2018.) 
Beebe, George. "Thank You for Sharing: A Rare Counterterror Win for U.S.-Russian Relations." National Interest, December 19, 2017. https://nationalinterest.org/ feature/thank-you-sharing-rare-counterterror-win-us-russian-23720. (Accessed 20 February 2019.)

Bennet, James. "Clinton Declares U.S., with World, Failed Rwandans.” New York Times, 26 March 1998: A6, A12.

Boister, Neil. "Responding to Transnational Crime: The Distinguishing Features of Transnational Criminal Law." Chapter 2, 27-49. In Harmen Van Der Wilt and Christophe Paulussen, eds., Legal Responses to Transnational and International Crimes. Cheltenham, UK: Edward Elgar, 2017.

Braber, Inez. "Terrorism as a New Generation Transnational Crime: Prosecuting Terrorism at the International Criminal Court." Chapter 5: 92-106. In Harmen Van Der Wilt and Christophe Paulussen, eds., Legal Responses to Transnational and International Crimes. Cheltenham, UK: Edward Elgar, 2017. https://www.elgaronline.com/view/edcoll/9781786433985/ 9781786433985.00012.xml. (Accessed 20 February 2019.)

Briggs, E. Donald, Walter C. Soderlund, and Tom Pierre Najem. Syria, Press Framing, and the Responsibility to Protect. Baltimore: Project Muse, 2017.

Bui, Doan. "The Korean Raqqa Who Wanted to 'Fuck France' Sentenced to 10 Years in Prison". December 17, 2016. https://www.nouvelobs.com/justice/ 20161215.OBS2747/le-coreen-de-raqqa-qui-voulait-niquer-la-france-condamnea-10-ans-de-prison.html. Translated from French to English. (Accessed December $31,2018)$.

Byman, Daniel. "Homecomings: What Happens When Arab Foreign Fighters in Iraq and Syria Return?” Studies in Conflict \& Terrorism, 38 (2015): 581-602.

Byman, Daniel, and Jeremy Shapiro. "Be Afraid, Be a Little Afraid: The Threat of Terrorism From Foreign Fighters in Syria and Iraq." Brookings Institution. 12 January 2015. https://www.brookings.edu/research/be-afraid-be-a-little-afraidthe-threat-of-terrorism-from-western-foreign-fighters-in-syria-and-iraq/. (Accessed 20 February 2019.)

Chesterman, S. "Dogs of War or Jackals of Terror? Foreign Fighters and Mercenaries in International Law," International Community Law Review, 18( 2016).

Central Intelligence Agency (CIA). World Factbook (Washington, DC, 2019). https://www.cia.gov/library/publications/the-world-factbook/geos/sy.html.

Cohen, Zachary. “Trump Administration Attempts to Soothe Allies' Worries Over Syria Troop Withdrawal.” CNN, December 29, 2018 
De Guttry, Andrea, Francesca Capone, and Christophe Paulussen (eds.). Foreign Fighters Under International Law and Beyond. The Hague: Asser Press, 2016.

De Standaard. "Welke Straf Krijgt Elke Beklaagde?" ("What Punishment Does Each Defendant Receive?”). De Standaard, February 10, 2015. http://www.standaard.be/cnt/dmf20150210_01521286. (Accessed December 31, 2018.)

Donnelly, Maria, Thomas Sanderson, and Zack Fellman. "Case Studies in History: Afghanistan, Bosnia, Chechnya." Center for Strategic and International Studies (CSIS), Transnational Threats Project, n.d. http://foreignfighters.csis.org/ history/case-studies.html. (Accessed 20 February 2019.)

Dunoff, Jeffrey L., Steven R. Ratner, and David Wippman. International Law: Norms, Actors, Process: A Problem-Oriented Approach. Third Edition. New York: Aspen, 2010.

Faber, Sebastiaan. "Spain's Foreign Fighters: The Lincoln Brigade and the Legacy of Spanish Civil War," Foreign Affairs, Sept/Oct. 2016.

https://www.foreignaffairs.com/reviews/review-essay/spain-s-foreign-fighters. (Accessed August 31, 2018.)

Gillett, Matthew, and Matthias Schuster. “Fast-Track Justice,” Journal of International Criminal Justice 9(2011): 989-1020.

Greenberg, Karen, ed. "The American Exception: Terrorism Prosecutions in the United States-The ISIS Cases, March 2014 to August 2017." https://static1.squarespace.com/static/55dc76f7e4b013c872183fea/t/59cf980ae45a 7c855f673bca/1506777101200/The+American+Exception+9-17.pdf . (Accessed 23 February 2019.)

Gurski, Phil. Western Foreign Fighters: The Threat to Homeland and International Security. Lanham, MD: Rowman \& Littlefield, 2017.

Hagel, Chuck. "ISIS: We've Never Seen Anything Like It.” Video. 20 November 2014. https://www.theguardian.com/world/video/2014/nov/20/isis-us-defence-secretarychuck-hagel-video.

Hall, John, and Peter Allen. "Find Jihadi John's Execution Squad.” Daily Mail Online, November 18, 2014. https://www.dailymail.co.uk/news/article-2839065/FindJihadi-John-s-execution-squad-Massive-manhunt-international-ISIS-assassinsintensifies-family-French-scooter-salesman-converted-Catholicism-speakhorror.html. (Accessed 20 February 2019.) 
Hegghammer, Thomas, and Jeff Colgan. "Islamic Foreign Fighters: Concept and Data." Paper presented at the International Studies Association Annual Convention, Montreal, 2011.

Herridge, Catherine, and Nadiah Sarsour. "“Till We Run Out of Fuel and Bullets': Jordan's King Vows to Crush ISIS.” FOX News, 5 February 2015.

John, Tara. "Everything You Need To Know About the New Nusra Front," Time Magazine, July 282016.

Jones, Seth, and Maxwell Markusen. "The Escalating Conflict with Hezbollah in Syria." Center for Strategic and International Studies (CSIS), June 20, 2018. https://www.csis.org/analysis/escalating-conflict-hezbollah-syria. (Accessed 20 February 2019.)

Kaplow, Larry. "History of U.S. Responses to Chemical Weapons Attacks in Syria." National Public Radio, 14 Apr. 2018. www.npr.org/sections/thetwoway/2018/04/13/602375500/history-of-u-s-responses-to-chemical-weaponsattacks-in-syria. (Accessed December 31, 2018)

Karska, E., and K. Karski. "Introduction: The Phenomenon of Foreign Fighters and Foreign Terrorist Fighters.” International Community Law Review, 18 (2016): 377-387.

Labbé, Chine. "French Court Jails First Returning Syria Jihadi for Seven Years." Reuters. November 13, 2014. Accessed December 31, 2018.

https://uk.reuters.com/article/uk-france-jihadi/french-court-jails-first-returningsyria-jihadi-for-seven-years-idUKKCN0IX1WG20141113. (Accessed 31 December 2018.)

Laub, Zachary. "Who’s Who in Syria’s Civil War." Council on Foreign Relations. April 28, 2017. https://www.cfr.org/backgrounder/whos-who-syrias-civil-war. (Accessed 31 December 2018.)

Lowe, A. V. The United Nations Security Council and War: The Evolution of Thought and Practice Since 1945. Oxford: Oxford University Press, 2008.

Mahfoudh, H. "Protect, Respect and Remedy: A Framework for Accountability for Human Rights Violations Committed by Foreign Fighters." International Community Law Review, 18 (2016), 418-430.

Malet, D. and M. Anderson. Transnational Actors in War and Peace. Washington, DC: Georgetown University Press, 2017. 
Marcus, Jonathan. “Trump Re-imposes Iran Sanctions: Now What?” BBC News, 3 November 2018. https://www.bbc.com/news/world-middle-east-46075179. (Accessed January 01, 2019.)

McKernan, Bethan. "Foreign ISIS Fighters Must Face Trial on Home Soil, Kurds Say." Guardian, September 24, 2018. https://www.theguardian.com/world/2018/ sep/24/foreign-isis-fighters-must-face-trial-on-home-soil-kurds-say. (Accessed 14 August 2018.)

Meko, Tim. "Now That the Islamic State Has Fallen in Iraq and Syria, Where Are All Its Fighters Going?" Washington Post, February 22, 2018.

https://www.washingtonpost.com/graphics/2018/world/isis-returningfighters/?utm_term=.f650984e68c8. (Accessed 14 August 2018.)

Melamed, Avi. “Iran Can’t Fulfill Its Hopes of a Shia Corridor Without Iraq.” Atlantic Council, October 11, 2018. https://www.atlanticcouncil.org/blogs/iransource/irancan-t-fulfill-its-hopes-of-a-shia-corridor-without-iraq .(Accessed 11 December 2018.)

Milanovic, Marko, "Courting Failure: When are International Criminal Courts Likely to Be Believed by Local Audiences?" In K.J. Heller, F. Megret, S. Nouwen, J. Ohlin, and D. Robinson, eds., The Oxford Handbook of International Criminal Law. Oxford: Oxford University Press, forthcoming. Article available at https://ssrn.com/abstract=2887090. (Accessed 24 February 2019.)

Milanovic, Marko, "The Impact of the ICTY on the Former Yugoslavia: An Anticipatory Postmortem," American Journal of International Law 110 (2016): 233-259.

Moore, Jack. "France: First Jihadist Sentenced for Fighting in Syria Flavien Moreau Handed Seven Years. IB Times, November 13, 2014. https://www.ibtimes.co.uk/ france-first-jihadist-sentenced-fighting-syria-flavien-moreau-handed-seven-years1474688 . (Accessed 26 November 2018.)

Neumann, Peter R. "Foreign Fighter Total in Syria/Iraq Now Exceeds 20,000; Surpasses Afghanistan Conflict in the 1980s." International Centre for the Study of Radicalization and Political Violence, 26 January 2015. http://icsr.info/2015/01/ foreign-fighter-total-syriairaq-now-exceeds-20000-surpasses-afghanistan-conflict1980s/. (Accessed 12 June 2015.)

Pace, Julie. “Obama Orders Airstrikes In Syria For First Time.” Associated Press, September 11, 2014. https://apnews.com/1c712f30c20e42099898ca3b0984017d. (Accessed 18 October 2018.)

Phillips, Christopher. The Battle for Syria: International Rivalry in the New Middle East. New Haven, CT: Yale University Press, 2016. 
Polyakova, Alina. "Putin's True Victory in Syria Isn't Over ISIS.” Brookings Institution, 1 March 2018. www.brookings.edu/opinions/putins-true-victory-in-syria-isntover-isis/. (Accessed 17 December 2018.)

Power, Samantha. A Problem from Hell: America and the Age of Genocide. New York: Basic Books, 2013.

Risen, Tom. “Arms Sales Boom Amid Iran, Saudi Arabia Proxy Wars.” U.S. News \& World Report. 22 February 2016. https://www.usnews.com/news/blogs/datamine/2016/02/22/arms-sales-boom-amid-iran-saudi-arabia-proxy-wars. (Accessed 29 August 2018.)

Rome Statute of the International Criminal Court. Article 5. 12 July 1999. http://legal.un.org/icc/statute/99_corr/2.htm. (Accessed 20 February 2019.)

Saad, Hwaida. "Syria Regains Control of Damascus, After Seven Years of Fighting". March 21, 2018. New York Times. https://www.nytimes.com/2018/05/21/world/ middleeast/syria-damascus-rebels.html. (Accessed 21 December 2018.)

Santos, Michael Dos. "Second French Citizen Identified as Islamic State Executioner." Irish Times, 20 November 2014. https://www.irishtimes.com/news/world/secondfrench-citizen-identified-as-islamic-state-executioner-1.2007908. (Accessed 22 September 2018.)

Savage, Charlie. "As ISIS Fighters Fill Prisons in Syria, Their Home Nations Look Away." New York Times, July 18, 2018. https://www.nytimes.com/2018/07/18/ world/middleeast/islamic-state-detainees-syria-prisons.html . (Accessed 2 January 2018.)

Scharf, Michael P. "Special Tribunal for Lebanon Issues Landmark Ruling on Definition of Terrorism and Modes of Participation." American Society of International Law, Insights (15) March 4, 2011. https://www.asil.org/insights/ volume/15/issue/6/special-tribunal-lebanon-issues-landmark-ruling-definitionterrorism-and-modes-of-participation. (Accessed 24 February 2019.)

Sievers, Loraine, and Sam Daws. The Procedures of the UN Security Council. Fourth Edition. Oxford: Oxford University Press, 2014.

Simcox, Robin. "When ISIS Fighters Return Home.” Heritage Foundation, 21 March 2018. https://www.heritage.org/terrorism/commentary/when-isis-fighters-returnhome. (Accessed 7 June 2018.)

Sivakumaran, S. "Re-Envisaging the International Law of Internal Armed Conflict." European Journal of International Law 22 (2011): 2019-2064. 
Sorenson, D. Syria in Ruins: The Dynamics of the Syrian Civil War. Santa Barbara, CA: Praeger/ABC-CLIO, 2016.

(The) Soufan Group. "Foreign Fighters: An Updated Assessment of the Flow of Foreign Fighters into Syria and Iraq." December 2015. http://soufangroup.com/wpcontent/uploads/2015/12/TSG_ForeignFightersUpdate_FINAL3.pdf. (Accessed December 31, 2018.)

Stark, Barbara. International Law and Its Discontents : Confronting Crises. New York: Cambridge University Press, 2015.

Strom, Margot Stern. Facing History and Ourselves: Holocaust and Human Behavior. New York: Facing History and Ourselves Foundation, 2014.

Taub, Ben. "What Happens to Former ISIS Fighters?” New Yorker, 3 September 2015. https://www.newyorker.com/news/news-desk/what-happens-to-former-isisfighters. (Accessed 20 February 2019.)

Times of Israel staff. "IDF Official Said to Confirm Attack in Syria: 'First Strike on Iranian Targets'." Times of Israel, 16 April 2018. www.timesofisrael.com/idfofficial-confirms-attack-in-syria-first-strike-on-live-iranian-targets/. (Accessed 12 July 2018.)

Tolbert, David. "Introduction: A Very Special Tribunal." Chapter 1. In Amal Alamuddin, Nabil Jurdi, and David Tolbert, The Special Tribunal for Lebanon: Law and Practice Oxford: Oxford University Press, 2014.

United Nations High Commissioner for Refugees (UNHCR). "Syria Regional Refugee Response," Updated 20 December 2018. https://data2.unhcr.org/en/situations/ syria\#_ga=2.73354515.1220391432.1539884780-4235111.1539884780 .

(Accessed December 31, 2018.)

United Nations Human Rights Council (UNHRC). "Out of Sight, Out of Mind: Deaths in Detention in Syria." Report of the Secretary-General, A/HRC/31/CRP.1, Appendix 1. February 3, 2016. https://www.ohchr.org/Documents/HRBodies/ HRCouncil/CoISyria/A-HRC-31-CRP1_en.pdf .

United Nations Human Rights Council (UNHRC). "Rule of Terror: Living under ISIS in Syria." Report of the Independent International Commission of Inquiry on the Syrian Arab Republic. Resolution A/HRC/27/CRP.3, 19 November 2014.

United Nations Office of the High Commissioner (UNOHC). "Statement by the Commission of Inquiry on Syria, on the second anniversary of the August 3, 2014 attack by ISIS on the Yazidis," 3 August 2016. https://www.ohchr.org/EN/ NewsEvents/Pages/DisplayNews.aspx?NewsID=20330\&LangID=E. (Accessed 23 February 2019.) 
United Nations Security Council (UNSC). "Implementation of Security Council Resolution 2178 (2014) By States Affected by Foreign Terrorist Fighters." https://www.un.org/sc/ctc/wp-content/uploads/2016/.../FTF-Report-13_English.pdf. (Accessed 20 February 2019.)

United Nations Security Council (UNSC). Resolution S/RES/955. November 8, 1994. https://undocs.org/S/RES/955(1994)

Van Der Wilt, Harmen, and Christophe Paulussen. Legal Responses to Transnational and International Crimes: Toward an Integrative Approach. Cheltenham, UK: Edward Elgar, 2017.

Walzer, Michael. Just and Unjust Wars : A Moral Argument with Historical Illustrations. Fifth Edition. New York: Basic Books, 2015.

Wille, Belkis. "Four Years On, Evidence of ISIS Crimes Lost to Time." Human Rights Watch, 3 August 2018. https://www.hrw.org/news/2018/08/03/four-yearsevidence-isis-crimes-lost-time. (Accessed 31 December 2018.)

Wright, Robin. "ISIS Makes a Comeback as Trump Opts to Stay in Syria." New Yorker, 30 August 2018. www.newyorker.com/news/news-desk/isis-makes-acomebackas-trump-opts-to-stay-in-syria. (Accessed 18 December 2018.) 